\title{
BIOSYNTHETIC PATHWAYS FROM ACETATE TO NATURAL PRODUGTS
}

\author{
F. LYNEN \\ Max-Planck-Institute for Cell Chemistry, Münich, Germany
}

\section{INTRODUCTION}

Investigations during the last three decades have shown that ace ic acid is one of the most important building units for the synthesis of complex organic molecules found in Nature. This insight is primarily due to the application of tracer techniques to biosynthetic problems. Despite all the admiration this method deserves, we should not forget, however, that organic chemists, full of imagination, earlier recognized common structural features in different molecules, and postulated biosynthetic schemes and special rules, which could be used in structural studies on new natural products with great success. The special rules I have in mind are the "isoprene rule" of Ruzicka ${ }^{1}$ and the "polyacetate rule" of Birch". Today every organic chemist interested in natural products must be familiar with both rules, and thus I need not dwell on their wide-spread application. Furthermore, a number of excellent reviews on this subject exist (cf.ref. 3). Therefore I want to restrict myself to indicating briefly the fundamental principles of both rules, and then discuss in greater detail the enzymatic systems which participate in the accompanying biosynthetic reactions. Here I want to emphasize some recent studies in my laboratory.

\section{BIOSYNTHETIC PATHWAY via "ISOPRENE RULE"}

The "isoprene rule" originated from structural investigations of the volatile terpene oils. Otto Wallach and others studying the structural class of monoterpenes realized the relationship between this group of compounds and the simple unsaturated hydrocarbon isoprene. But it was Ruzicka's fundamental observation that this structural element is broadly distributed among many classes of natural products ${ }^{1}$.

The "isoprene rule" was clarified when $\Delta^{3}$-isopentenyl pyrophosphate (I) was identified to be the building block of the terpenes, ${ }^{4,5}$. Isopentenyl pyrophosphate can be considered as a "disguised" isoprene because elimination of pyrophosphoric acid would lead to isoprene (II).

$\mathrm{CH}_{2}=\stackrel{\mathrm{CH}_{3}}{\mathrm{C}}-\mathrm{CH}_{2}-\mathrm{CH}_{2}-\mathrm{OP}_{2} \mathrm{O}_{6} \mathrm{H}_{3} \longrightarrow$

(I)<smiles>C=C(C)C=C[PH2+]O</smiles> 


\section{Terpene biosynthesis}

Biosynthesis involving isopentenyl pyrophosphate--the later phase

The synthesis of the terpenoid carbon chains involves C-alkylation (cf. Figure 1). This is made possible by the bifunctional nature of isopentenyl pyrophosphate, based on the nucleophilic reactivity of the double bond and the potential electrophilic character of the pyrophosphate ester. The process is initiated by the isomerization of isopentenyl pyrophosphate to $\gamma, \gamma$-dimethylallyl pyrophosphate by a shift of the double bond. With the formation of dimethylallyl pyrophosphate the electrophilic reactivity of the precursor isopentenyl pyrophosphate is fully realized. Ionization of the carbonoxygen bond of the dimethylallyl pyrophosphate creates a cationic centre
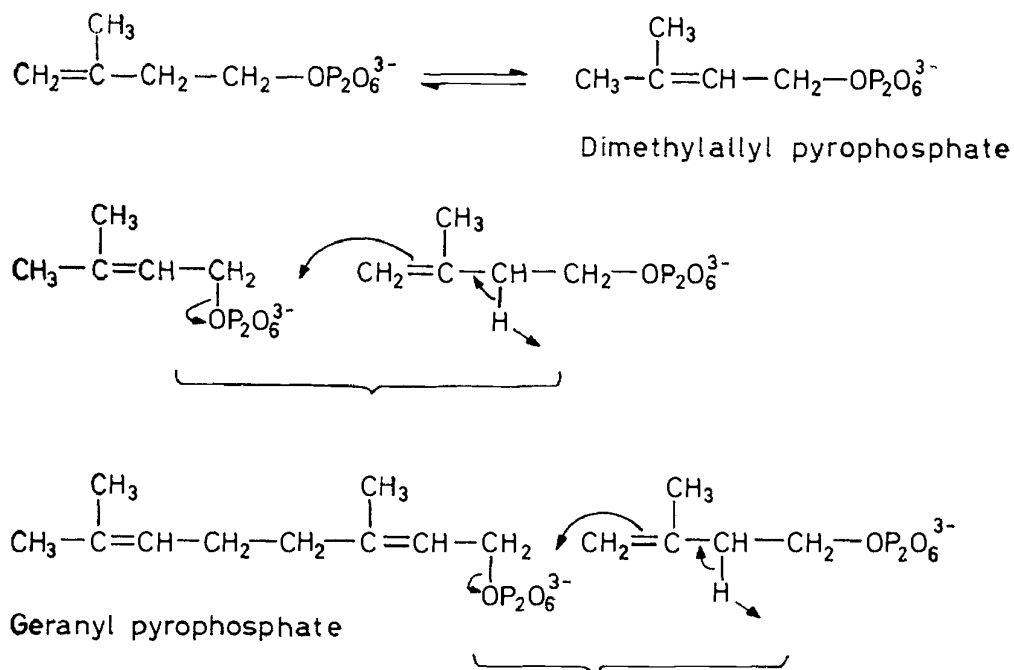

\section{Farnesyl pyrophosphate}

Figure 1. The mechanism of the synthesis of isoprenoid carbon chains

which then attacks the electrons available in the exomethylene group of isopentenyl pyrophosphate. Subsequently, the elimination of a proton leads to the first condensation product, geranyl pyrophosphate. This homologous allyl pyrophosphate by acquisition of another isopentenyl pyrophosphate is converted into farnesyl pyrophosphate, the direct precursor of the sesquiterpenes. A continuation of this process leads to geranyl-geranyl pyrophosphate, from which the diterpenes can be derived, or to the higher linear arrays that are found in the ubiquinones, plastoquinones or gutta percha. The steric course of chain growth, whether olefinic linkages with trans or cis stereochemistry are produced, depends on the stereospecificity of the enzyme involved. As was demonstrated by Archer et al. ${ }^{6}$, the polymerizing enzyme from Hevea latex, catalysing the production of natural rubber (the all $c_{i}$ s polyisoprene), eliminates a proton epimeric with that eliminated in the synthesis of the trans compound farnesyl pyrophosphate. 


\section{BIOSYNTHETIG PATHWAYS FROM ACETATE TO NATURAL PRODUCTS}

The reactivity of allylic pyrophosphate may be due to two combined effects: $(i)$ the ease of displacement of the pyrophosphate anion, and (ii) the resonance stabilization of the allylic carbonium ion. The fact that pyrophosphoric acid is more strongly acidic than orthophosphoric acid and consequently is a better leaving group is also evidenced by the increased rate of acid hydrolysis of allyl pyrophosphates compared with that of allyl phosphates? ${ }^{2}$. In addition, the pyrophosphate residue of isopentenyl pyrophosphate may exert a neighbouring group effect on the alkylation, as suggested by Johnson and Bell ${ }^{8}$.

The crucial role played by the isomerase in the chain of terpene biosynthesis is obvious. It catalyses the isomerization of isopentenyl pyrophosphate to the allylic derivative and thus triggers the synthesis of the terpene chain. Once this process has started it can continue without renewed isomerization, and is limited only by the specificity of the participating enzymes. This was first shown in our laboratory by experiments with the enzyme system of yeast catalysing the synthesis of farnesyl pyrophosphate ${ }^{9}$. We were able to demonstrate it again in more recent studies on rubber biosynthesis.

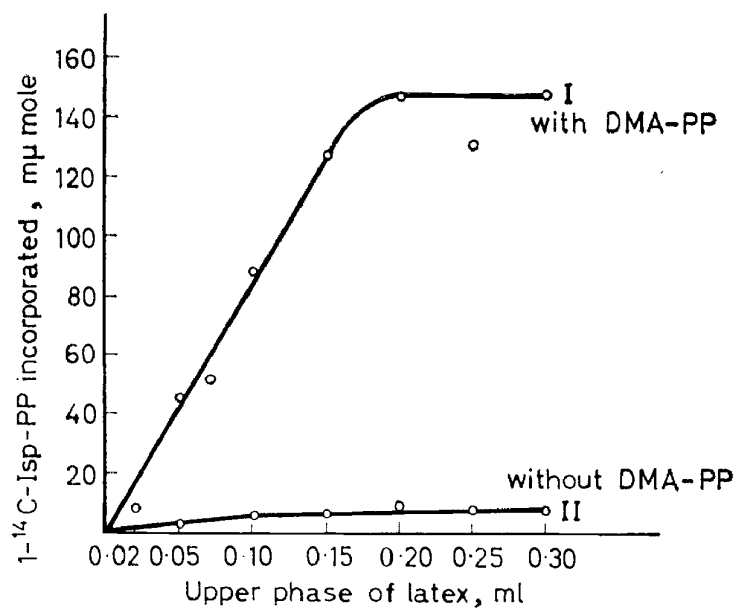

Figure 2. Incorporation of $1^{1-14} \mathrm{C}$-isopentenyl pyrophosphate (Isp-PP) into rubber with and without addition of dimethylallyl pyrophosphate (DMA-PP). An $0.8 \mathrm{ml}$ reaction mixture contained (in $\mu$ moles): TRIS buffer, $\mathrm{pH} 8.0,100 ; \mathrm{MgK}_{2}$-ethylenediamine tetraacetate, 20; $\mathrm{MgCl}_{2}, 2$; cysteine, $5 ; 1-14 \mathrm{C}$-isopentenyl pyrophosphate $\left(2.1 \times 10^{5} \mathrm{c} . \mathrm{p} . \mathrm{m} . / \mu \mathrm{mole}\right), 0.17$; and the resuspended creamy upper phase of centrifuged Hevea latex, as indicated on the abscissa. The experiments of curve I contained in addition $0 \cdot 1 \mu$ moles of dimethylallyl pyrophosphate. After $120 \mathrm{~min}$ incubation at $26^{\circ} \mathrm{G}$ the rubber was isolated and its radioactivity measured

As Henning ${ }^{10}$ had found in my laboratory some years ago, freshly tapped latex from the rubber tree Hevea brasiliensis catalyses the incorporation of synthetic $1{ }^{14} \mathrm{C}$-isopentenyl pyrophosphate into rubber, a fact which was later confirmed by Archer et al. ${ }^{11}$ In collaboration with Hopper, Nordwig, Berndt, and Dick we continued these studies. One of the problems involved was to find a good supply of Hevea latex. By the generous support of Professor Milanez, then director of the famous botanical garden in Rio de Janeiro, we were allowed to use one of the Hevea trees of the garden as a 


\section{F. LYNEN}

source of latex. Dr. Raoul Machado expertly tapped the tree, collected the latex, added cysteine and bicarbonate as protective agents and sent the material, after freezing it in dry ice, by aeroplane to Munich. In this way we received the enzymatically active material 24 hours after its harvest in Rio de Janeiro. By centrifugation of the thawed material at $20000 \mathrm{~g}$ it separated into a slightly opalescent aqueous bottom phase, and a creamy top layer, which contained the bulk of the preformed rubber and the polymerizing enzyme. This polymerase remained in the creamy layer during repeated washing with TRIS-buffer, $\mathrm{pH} 8 \cdot 0$, containing serum albumin and TWEEN. By this treatment the isomerase was removed completely, and the incorporation of $1-{ }^{14} \mathrm{C}$-isopentenyl pyrophosphate into high molecular rubber became now strictly dependent on the addition of dimethylallyl pyrophosphate as "primer" of the polymerization (Figure 2). The Michaelis constant of the polymerase for dimethylallyl pyrophosphate was found to be $1.3 \times 10^{-5}$ м (Figure 3).

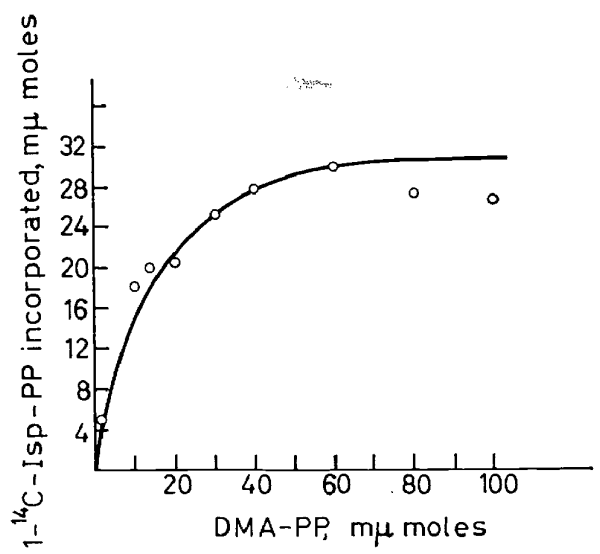

Figure 3. Dependence of rubber synthesis on the concentration of dimethylallyl pyrophosphate. Experimental conditions were identical to those of Figure 2 except that the final volume was $0.5 \mathrm{ml}$. The reaction mixtures contained $0.1 \mathrm{ml}$ of upper phase of Hevea latex and dimethylallyl pyrophosphate (DMA-PP) as indicated on the abscissa

These results may be interpreted with the assumption that the polymerization of $\mathrm{C}_{5}$-units to high molecular rubber is catalysed by one enzyme. The close association of this enzyme with the rubber droplets of the emulsion appears most appropriate from the physiological point of view, because otherwise the reaction product, rubber, could not be remcved from the surface of the enzyme. We assume therefore that the polymerase is located at the surface area of the small rubber droplets, where it can accept the water-soluble substrates from the serum and deliver the synthesized hydrocarbon into the hydrophobic phase. In contrast to the polymerase the enzymes involved in the biosynthesis of isopentenyl pyrophosphate from acetate, which will be discussed later, are present in the aqueous serum fraction. Anticipating any discussion, I would like to present in Table 1 the 
Table 1. Activity of the enzymes involved in rubber synthesis

\begin{tabular}{l|c}
\hline \multicolumn{1}{c|}{ Enzyme } & $\begin{array}{c}\text { Enzyme activity }\left(37^{\circ}\right) \\
\text { (m } \mu \text { moles of substrate/min/ml latex) }\end{array}$ \\
\hline Acetyl-CoA synthetase & 59 \\
Thiolase & $3.92(3920 \dagger)$ \\
HMG-CoA synthase & 232 \\
HMG-CoA reductase & 0.078 \\
Mevalonate kinase & 449 \\
P-Mevalonate kinase & 103 \\
PP-Mevalonate decarboxylase & - \\
Isopentenyl-PP isomerase & $22 \cdot 3$ \\
Polymerase & \\
\hline
\end{tabular}

$\dagger$ for the reverse reaction.

results of our quantitative measurements of the various enzyme activities in the serum fraction. As can be seen all enzyme activities are of comparable magnitude with the exception of the $\beta$-hydroxy- $\beta$-methylglutaryl(HMG)-CoA reductase. This enzyme activity, which is responsible for the formation of mevalonic acid, is much lower, and it is conceivable that this enzymatic step may represent the physiological bottleneck of rubber biosynthesis. From the point of view of comparative biochemistry this observation seems to be very important since $\mathrm{HMG}-\mathrm{CoA}$ reduction is also the ratelimiting step of cholesterol synthesis in the mammalian organism (cf. page 148).

There is every reason to believe that isopentenyl pyrophosphate functions universally as the "monomeric" precursor for the great variety of linear and cyclic isoprene derivatives which occur in Nature. The sequence of events seems to be always the same. Following the synthesis of open chain terpenyl derivatives, secondary transformations such as reduction, cyclization, rearrangement, and oxidation reactions lead to the reduced, cyclized, and oxygenated terpenoid compounds. Interception by an activated aromatic ring or by protohaeme will lead to natural products like ubiquinones, vitamins $\mathrm{K}$ or haeme $\mathrm{a}^{\mathbf{1 2}}$.

I do not want to go further into details about secondary transformations of open chain terpenyl derivatives, because apart from the synthesis of lanosterol and cholesterol, little is known about the enzymes involved. Biosynthetic experiments with isotopically labelled precursors have in many cases revealed that reaction mechanisms predicted by applying the rules of organic chemistry agree very well with the isotope distribution found experimentally (cf. ref. 3). The most brilliant example is the experimental verification of the theoretical model of triterpene biogenesis, constructed by the Zürich school $^{13}$.

Among the various transformations in the field of terpene biochemistry, the dimerization of farnesyl pyrophosphate to squalene deserves particular mention. This process (cf. Figure 4) represents the prototype of the "tail to tail" linkage of $\mathrm{C}_{5}$-units, first represented by Ruzicka ${ }^{1}$ as an irregular type of condensation in the biosynthesis of terpenes. Since the reductive dimerization of two molecules of farnesyl pyrophosphate occurs with simultaneous elimination of the pyrophosphate residues, this reaction in a formal sense 


\section{F. LYNEN}

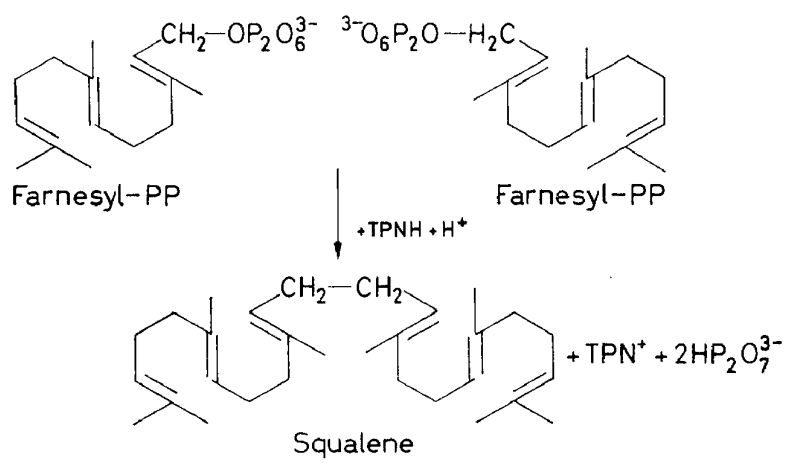

Figure 4. Balance equation for the formation of squalene from farnesyl pyrophosphate

resembles Karrer's ${ }^{14}$ chemical synthesis of squalene from farnesyl bromide and magnesium.

In the case of the enzymatic synthesis TPNH assumes the role of electron donor. The detailed chemical mechanism of squalene synthesis from two molecules of farnesyl pyrophosphate is still obscure ${ }^{3}$. But the beautiful work of Cornforth et al.$^{15}$ has not only elucidated the stereochemistry of this process but also presented unequivocal proof that the condensation is an asymmetric process in the sense that one of the farnesyl pyrophosphate molecules condensing is subject to reactions different from those of the other.

\section{Biosynthesis involving mevalonic acid-the earlier phases}

Thus far I have discussed the later phase of terpene biosynthesis. Let us turn now to the discussion of earlier phases in which mevalonic acid occupies a central position. The discovery of mevalonic acid by Wright, Folkers, and associates (cf. ref. 16) at the Merck, Sharp, and Dohme laboratories ten years ago proved to be the real starting point for the elucidation of the chemical mechanism of terpene biosynthesis. Enzymatic experiments with radioactively labelled mevalonic acid in cell-free extracts and with purified enzymes from yeast or liver led to the isolation of "active isoprene" and its identification as isopentenyl pyrophosphate (cf. ref. 3).

The biological precursor of mevalonic acid (III) is $\beta$-hydroxy- $\beta$-methylglutaryl-CoA (IV), which is enzymatically reduced by TPNH (Figure 5). The particular enzyme involved in this reduction was purified from yeast extracts ${ }^{\mathbf{1 7}} \mathbf{1 8}$. When its mode of action was studied in greater detail it was found that free mevaldic acid (V) is not an intermediate in this reaction. For example, added mevaldic acid was only very slowly reduced by the purified enzyme. According to recent experiments of Dr. Rétey ${ }^{19}$, the semimercaptal of mevaldic acid with coenzyme A (VI) is much more rapidly reduced by the purified enzyme from yeast and seems to satisfy the kinetic requirements of an intermediate.

Pertaining to the conversion of mevalonic acid (III) to $\Delta^{3}$-isopentenyl pyrophosphate (I ; cf. Figure 6) by way of 5-phospho- (VII) and 5-pyrophosphomevalonic acid (VIII), the step that generates the biological 


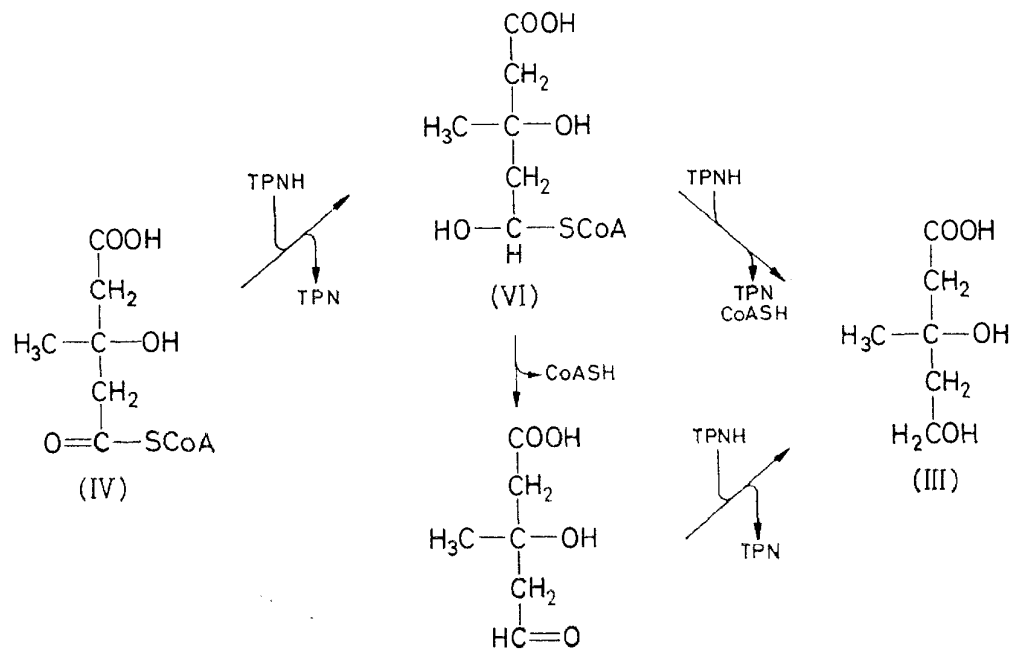

(V)

Figure 5. Possible mechanism of mevalonic acid formation from $\beta$-hydroxy- $\beta$-methylglutaryl-CoA

isoprene unit is chemically the most interesting reaction. The enzyme involved catalyses the coordinated removal of the carboxyl group and of the tertiary hydroxy function. Data of Bloch et al. ${ }^{20}$ obtained with ${ }^{18} \mathrm{O}$ suggest that 3-phosphomevalonic-5-pyrophosphate (IX), is a transitory intermediate, ATP serving as the phosphorylation agent for the tertiary hydroxyl group thereby promoting its elimination.<smiles>CC(O)(CCO)CC(=O)O</smiles>

(III)

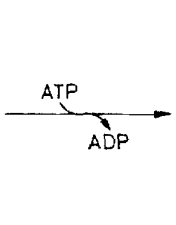<smiles>CC(O)(CCOP)CC(=O)O</smiles>

(VIII)

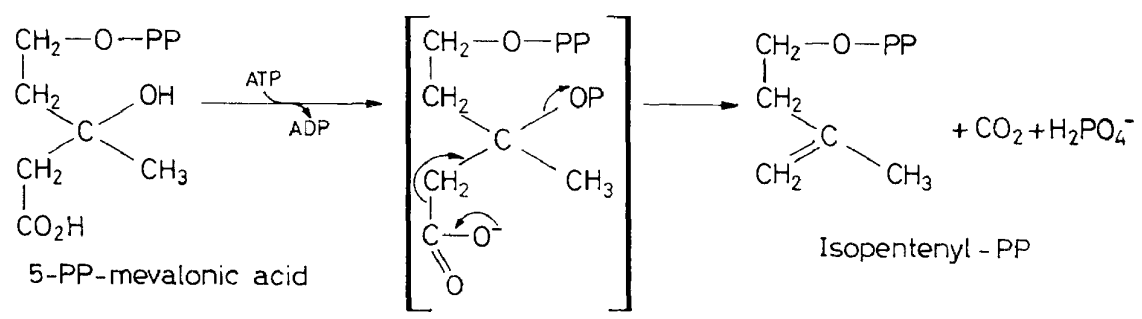

(IX)

Figure 6. The formation of $\Delta^{3}$-isopentenyl pyrophosphate from mevalonic acid 


\section{F. LYNEN}

Especially relevant to the topic of my lecture are the reactions leading to $\beta$-hydroxy- $\beta$-methylglutaryl-CoA from acetyl-CoA. Here the carbon skeleton of the $\mathrm{C}_{6}$-precursors of isopentenyl pyrophosphate is assembled by carbon to carbon condensation of three acetate units. The complete understanding of these reactions depends on the realization that an acetyl thioester is activated both at the carbonyl and the methyl group ("head" and "tail" end) ${ }^{21}$. In the condensation of two acetyl-CoA to form acetoacetylCoA both reactivities of the thioester are involved (Figure 7). One molecule

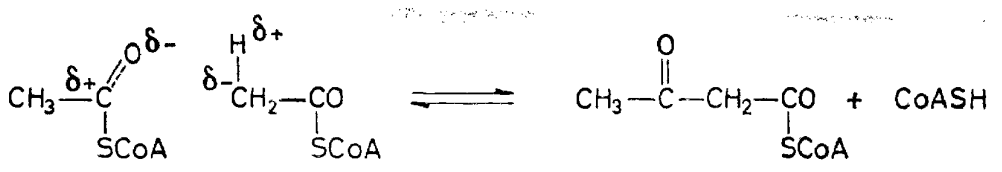

Figure 7. The mechanism of acetoacetyl-CoA formation

of acetyl-CoA is the nucleophilic agent and acetate acceptor and the other is the electrophilic acetyl donor. The condensation reaction is reversible and under physiological conditions the formation of acetyl-CoA from acetoacetyl-CoA is by far the preferred reaction. By means of spectrophotometric techniques it was possible to establish that at $\mathrm{pH} 7$ the equilibrium is ${ }^{21}$ :

$$
K_{\mathrm{eq}}=\frac{[\text { acetoacetyl-CoA }] \times[\mathrm{CoA}]}{[\text { acetyl-CoA }]^{2}}=1.6 \times 10^{-5}
$$

Nevertheless, it is possible to achieve the synthesis of carbon chains by thiolase reaction under physiological conditions, if the acetoacetyl-CoA produced is removed by subsequent condensation with acetyl-CoA (Figure 8 ). The condensation of acetyl-CoA and acetoacetyl-CoA to form $\beta$-hydroxy- $\beta$-methylglutaryl-CoA and free CoA seems to be irreversible. At least it was not

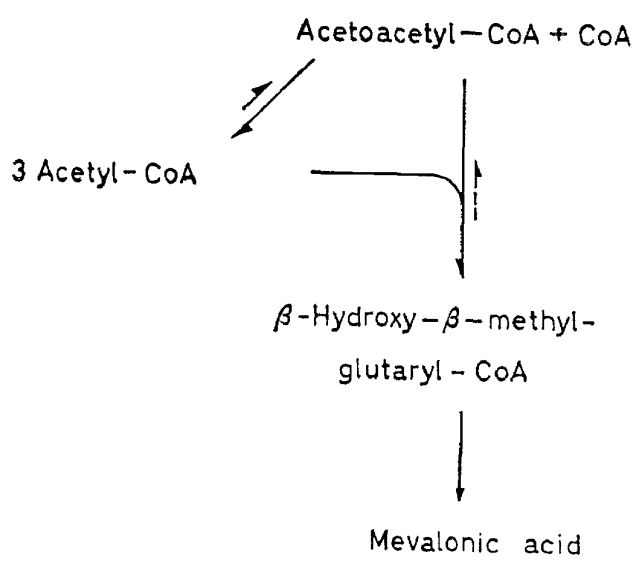

Figure 8. The coupling of thiolase reaction with hydroxymethylglutaryl-CoA synthase reaction 
possible to demonstrate any reversal of this condensation reaction even under conditions in which this should have been favoured ${ }^{17,18}$. Thus by coupling with the condensation the thiolase reaction can be forced in the direction of acetoacetyl-CoA formation with subsequent accumulation of $\beta$-hydroxy- $\beta$ methylglutaryl-CoA.

When I first studied the properties of the enzyme thiolase I found its high sensitivity against sulphydryl blocking agents and postulated that the active centre contained a sulphydryl group, which participated in the catalytic process $^{22}$. According to this hypothesis the acetoacetyl-CoA is cleaved by the $\mathrm{SH}$-enzyme with the generation of acetyl-CoA and an acetyl-S-enzyme. The acetyl-S-enzyme then transfers its acyl radical to coenzyme $A$ with the regeneration of the free SH-enzyme. Therefore thiolase should combine two activities:

Thiolytic activity as illustrated by reaction (1). Acyltransferase activity as illustrated by reaction (2).<smiles>CCCCCCCCCCCCC(=O)OC(C)=O</smiles><smiles>CC(=O)CCCCCSC(C)=O</smiles>

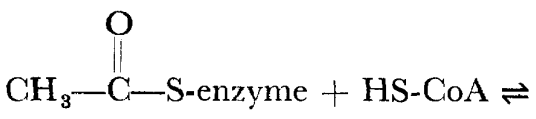

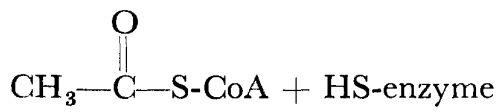

Gehring in my laboratory has now finally been able to prove this two step mechanism $^{23}$. He has achieved a 700 -fold purification of thiolase beginning with crude extracts from pig heart. The purified enzyme was homogeneous in the ultracentrifuge and could be crystallized by fractionation with ammonium sulphate. Its molecular weight was found ${ }^{24}$ to be 168000 .

In Figure 9 is summarized an experiment in which the reversible thiolytic step (a) was demonstrated independently of the acyltransferase step (b). Acetoacetyl-CoA was incubated with the purified enzyme and ${ }^{1-{ }^{14}} \mathrm{C}$-acetyl$\mathrm{CoA}$ for various periods of time and the distribution of radioactive carbon between carbonyl and carboxyl group of the coenzyme A bound acetoacetate was determined. As can be seen in Figure 9, the carboxyl carbon became highly radioactive whereas the carbonyl carbon remained practically without radioactivity. Similar asymmetric labelling was obtained previously by Beinert and Stansly ${ }^{25}$ with crude enzyme preparations. An interpretation of the asymmetric labelling of acetoacetate is as follows: The nonlabelled acetoacetyl-CoA forms nonlabelled acetyl enzyme in the forward reaction (1). This acetyl enzyme now condenses with $1-{ }^{14} \mathrm{C}$-labelled acetyl-CoA in 


\section{F. LYNEN}

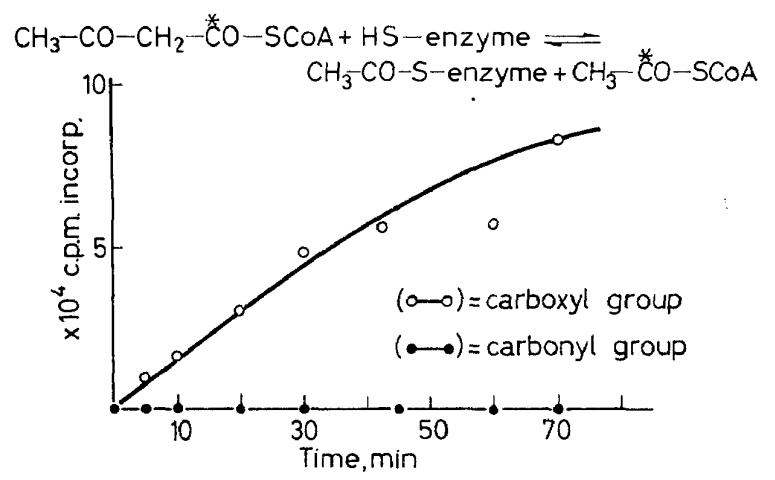

Figure 9. Incorporation of $1-{ }^{14} \mathrm{C}$-acetyl-CoA into the carboxyl group of acetoacetyl-CoA with thiolase ${ }^{23} .2 \mathrm{ml}$ reaction mixture, kept at $0^{\circ} \mathrm{C}$, contained in $\mu$ moles: K-phosphate, $\mathrm{pH} 7.5,60$; acetoacetyl-CoA, $0.5 ; 1{ }^{14} \mathrm{C}$-acetyl-CoA, 0.3 (3.35 × $10^{6}$ c.p.m.) $; 3 \mathrm{mg}$ serum albumin and $50 \mu \mathrm{g}$ thiolase (sp. activity 6). After various times of incubation aliquots were taken and the isotope distribution between keto carbon and carboxyl carbon was determined

the backward reaction (1) to give carboxyl-labelled acetoacetyl-CoA. The rate of interchange of acetyl groups between acetyl-CoA and acetyl enzyme is negligible because of the lack of free coenzyme A.

The formation of acetyl enzyme is further supported by the following experiment (Figure 10). Varying amounts of the purified enzyme were preincubated with ${ }^{1-14} \mathrm{C}$-labelled acetyl-CoA, then precipitated with trichloroacetic acid and carefully washed. As can be seen in Figure 10 the protein became radioactive in proportion to the amount of protein added, as to be expected if acetyl enzyme was generated with the acetyl radical covalently bound to the protein (equation 2). Studies on the interaction of thiolase with $1-{ }^{14} \mathrm{C}$-labelled iodoacetamide finally lead to the identification

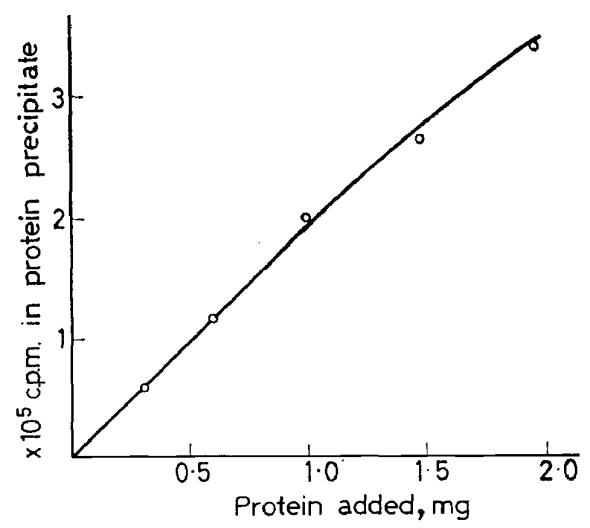

Figure 10. Demonstration of acetyl enzyme formation ${ }^{23}$. Each reaction mixture, vol. $1 \mathrm{ml}$, contained (in $\mu$ moles): K-phosphate, $\mathrm{pH} 7 \cdot 0,15$; glutathione, $5 ; 1$ - $^{14} \mathrm{C}$-acetyl-GoA, 0.1 $\left(2.7 \times 10^{6}\right.$ c.p.m. $) ; 4 \mathrm{mg}$ of serum albumin and thiolase, as indicated on the abscissa. After incubation for $10 \mathrm{~min}$ at $10^{\circ} \mathrm{C}$, the protein was precipitated with trichloroacetic acid, carefully washed and its fixed radioactivity determined 
of the acceptor group on the enzyme. In these experiments (cf. Figure 11) the kinetics of the inactivation of thiolase by $1-{ }^{14} \mathrm{C}$-iodoacetamide (full circles) was compared with the amount of iodoacetamide bound to the protein (open circles), which was measured by the radioactivity precipitated with trichloroacetic acid. As seen from Figure 11 the free enzyme is alkylated by iodoacetamide and is inactivated at the same time, whereas the acetyl enzyme generated by preincubation of the enzyme with acetoacetyl CoA (equation 1 ) is protected against interaction with iodoacetamide, and therefore remains enzymatically active. Thus it is reasonable to

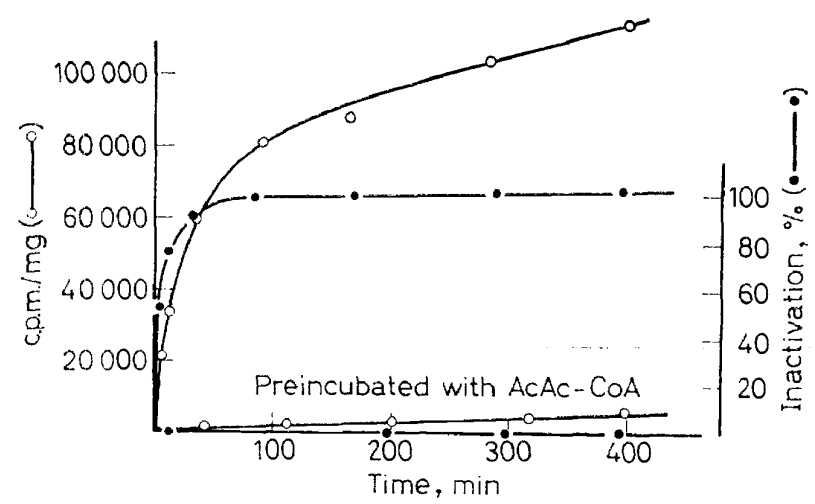

Figure 11. Interaction of $1-14 \mathrm{C}$-iodoacetamide with thiolase. Two reaction mixtures, vol. $5 \mathrm{ml}$, each contained 0.02 M TRIS-buffer, pH 8.2; $5 \times 10^{-5} \mathrm{M} \mathrm{1-14} \mathrm{C}$-iodoacetamide and $5 \cdot 2 \mathrm{mg}$ thiolase. One reaction mixture was preincubated with $7 \times 10^{-4} \mathrm{M}$ acetoacetyl-CoA before iodoacetamide was added. After various incubation times at $0^{\circ} \mathrm{C}$, as indicated on the abscissa, aliquots were withdrawn and thiolase activity (- $)$ as well as protein bound radioactivity $(\mathrm{O}-\ldots)$ were measured

assume that iodoacetamide reacts specifically with the acetyl acceptor group of the enzyme. Upon cleavage of the iodoacetamide treated enzyme with hydrochloric acid the radioactive fission product was identified as S-carboxymethyl cysteine by comparison with the authentic compound ${ }^{23}$. Quantitative measurements of the acetyl- and iodoacetamide binding capacity revealed that 3.6-3.7 residues are bound per enzyme molecule of molecular weight 168000 , which would indicate that thiolase belongs to the group of enzymes with tetrameric structure and is composed of four subunits each carrying one active SH-group. This assumption is further supported by studies on the reversible dissociation and inactivation of the enzyme treated with $5 \mathrm{~m}$ urea ${ }^{24}$.

It has been postulated ${ }^{26}$ that the initial condensation leading to the acetoacetate-level in terpene synthesis involves an acetyl unit and a malonyl unit as in the synthesis of long chain fatty acids. Energetically the mechanism would certainly be more favourable than the thiolase reaction. Bloomfield and Bloch ${ }^{27}$ have observed, however, that in biotin deficient yeast sterol synthesis from acetate proceeds normally, whereas fatty acid synthesis is greatly impaired. This result would seem to argue against any role of biotin catalysis, and therefore of malonyl units, in terpene synthesis from acetate.

The reaction sequence leading to terpenyl pyrophosphates, the precursors 


\section{F. LYNEN}

for all naturally occurring linear and cyclic isoprene derivatives, is summarized in Figure 12. The sequence can be divided into three sections. In the first section, the carbon skeleton of mevalonic acid is synthesized from three molecules of acetyl-CoA. The energy required for this process is derived from the three thioester bonds, which are cleaved to regenerate free coenzyme A, and the TPNH molecules, which become oxidized. In the second section

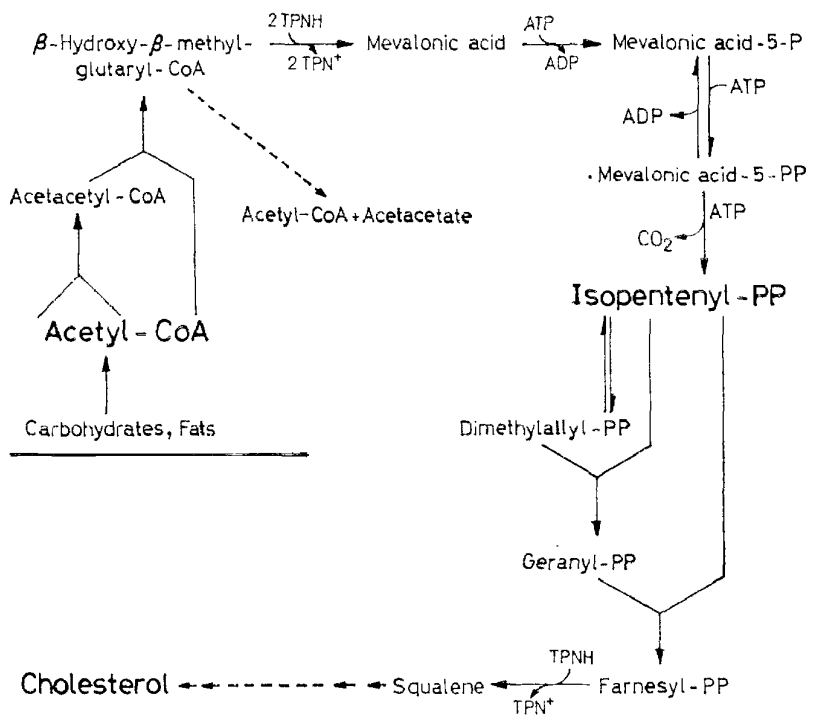

Figure 12. The route of the biosynthesis of polyterpenes

the conversion of mevalonic acid to isopentenyl pyrophosphate so suitable as the building unit for many natural products is achieved. This activation requires three moles of ATP and is simultaneously driven by a decarboxylation reaction. For the synthesis of the polyisoprenoid carbon chains in the last section, no additional source of energy is required, sufficient being made available by the expulsion of inorganic pyrophosphate from the allyl derivatives and its subsequent hydrolysis to orthophosphate by pyrophosphatase which is ubiquitous to all living systems.

All evidence to date indicates that changes in the activity of the enzyme responsible for the reduction of hydroxymethyglutaryl-CoA to mevalonic acid are in a direction and of a magnitude to account for the physiological control of polyisoprenoid biosynthesis. This was first realized in studies on cholesterol synthesis ${ }^{28}$ which can be virtually abolished by cholesterol feeding ${ }^{29-31}$ and by fasting ${ }^{32,33}$, or is increased by $x$-irradiation ${ }^{34}$ and intravenous injection of Triton WR-133935. The inhibition of hydroxymethylglutaryl-CoA reductase by cholesterol feeding seems to indicate that the principle of negative feed back operates in sterol biosynthesis as it does in so many pathways. With these considerations in mind the reductase step seems ideally suited to the control function, since it is the first step on the direct pathway to the polyisoprenoids and is essentially irreversible. Further- 
more hydroxymethylglutaryl-CoA generated in the condensation and not reduced to mevalonic acid, by the interaction of hydroxymethylglutaryl-CoA cleavage enzyme can be split into acetyl-CoA and acetoacetate, and thus channelled back to the acetate pool. Resuming an investigation which

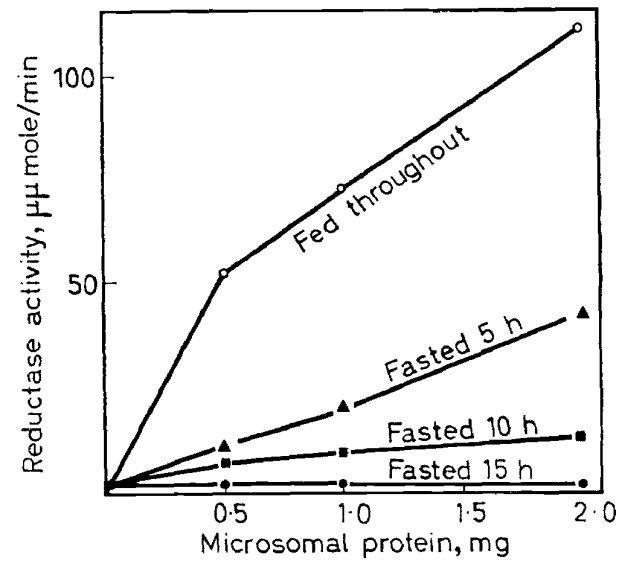

Figure 13. Effect of fasting on HMG-CoA-reductase activity in rat liver microsomes ${ }^{37}$

was started by Bucher ${ }^{36}$ during a short visit to my laboratory, Regen et al. ${ }^{37}$ systematically studied the changes in hydroxymethylglutaryl-CoA reductase activity of rat liver homogenates during a period of starvation and refeeding of animals.

The method for estimating the enzyme involved preparation of ${ }^{14} \mathrm{C}$-labelled hydroxymethylglutaryl-CoA and the separation of the labelled reduction product, mevalonic acid, by Celite column chromatography. The reductase was found to be firmly attached to the membraneous elements of the microsome fraction and to undergo drastic changes incident on brief

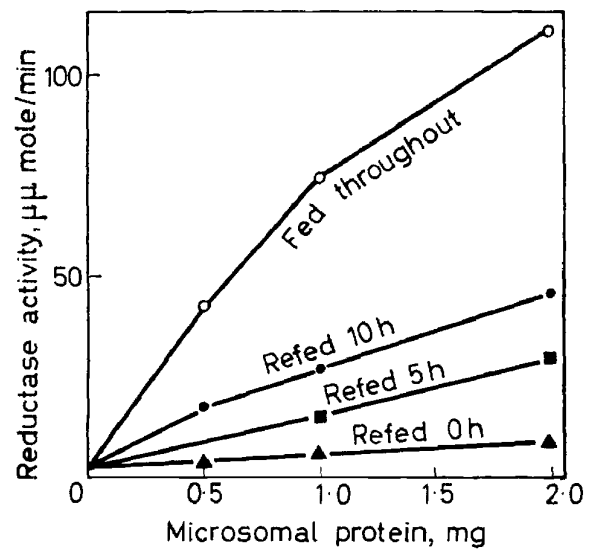

Figure 14. Effects of refeeding after a $20 \mathrm{~h}$ fast on the HMG-CoA reductase of liver microsomes ${ }^{37}$ 


\section{F. LYNEN}

food deprivation. We were surprised by the promptness of the response as seen in Figure 13. After only 5 hours the activity was less than 50 per cent of the fed control. The sudden fall in activity could represent a diminution of enzyme protein or a decrease in the catalytic ability of the protein due to a firmly bound inhibitor. At present further experiments are in progress which might decide between both possibilities. The effect of the standard diet on this enzyme is further illustrated by the restoration of activity upon refeeding after a 20-hour fast (cf. Figure 14). The response in this case appears somewhat slower.

\section{BIOSYNTHETIC PATHWAY via "POLYACETATE RULE"}

I shall now focus attention on the second pathway from acetate to natural products, which is governed by the "polyacetate rule". This biogenetic concept was first realized by Collie ${ }^{38}$ on the basis of some interesting transformations he had observed with polyacetyl compounds. However, it was not until 1953, when Birch ${ }^{2}$ in a brilliant re-examination of the concept laid down most of the modern view of the polyacetate hypothesis and not only pointed out its broad scope and great usefulness but also accumulated experimental support by studies with radioactive tracers.

The primary building block of this biosynthetic pathway was assumed to be a linear poly- $\beta$-ketomethylene, formed by repeated head-to-tail condensation
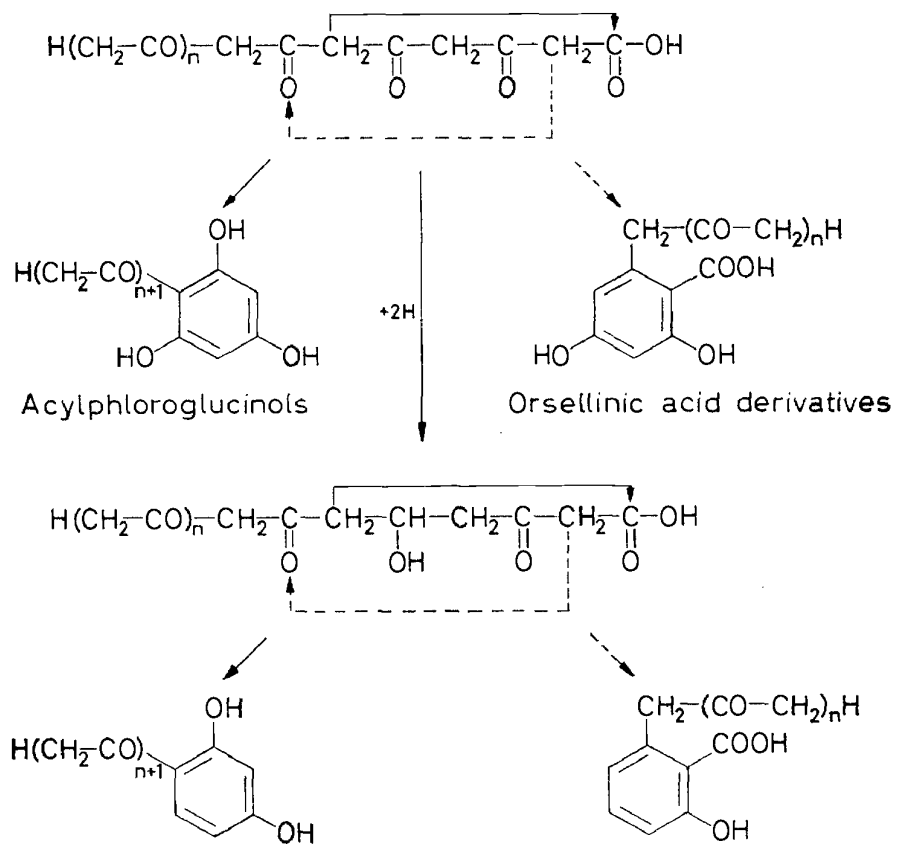

Acylresorcinols

Methylsalicylic acid derivatives

Figure 15. Illustration of the polyacetate-rule 
of acetate units (Figure 15). By secondary transformations, such as reduction, dehydration, condensation, cyclization, rearrangement, and decarboxylation reactions polyacetate molecules of different chain length can lead to an immense variety of naturally occurring organic molecules. Especially since additional variants are given by the introduction of methyl or isopentenyl groups at the methylene sites, or by replacement of acetic acid in the terminal position by another acid such as linear or branch chain aliphatic acids or some benzoic and cinnamic acids ${ }^{3}$.

One of the key reactions of the polyacetyl chain is cyclization. Thus an enolate anion may attack the carbonyl carbon of either keto or carboxyl group at another position of the chain to yield cyclized products, as illustrated in Figure 15. Both reactions occur with facility in forming six-membered rings and lead to two families of phenols, the acylphloroglucinol and orsellinic acid derivatives, respectively, distinguished by the aromatic substituent pattern. By reduction of a carbonyl group not involved in the cyclization and ring-closure by loss of water derivatives of methylsalicylic acid or acyl resorcinols respectively are generated.

With the detection of the thioester bond in acetyl-CoA and the identification of the enzyme, thiolase, the enzymatic problem of the polyacetate synthesis seemed to be essentially solved ${ }^{39}$. It was assumed that repeated condensations of acetyl-CoA molecules could generate poly- $\beta$-ketomethylene structures. On the other hand the value found for the equilibrium of the thiolase reaction, mentioned earlier in my lecture, was difficult to reconcile with this hypothesis. By simple calculations we were able to demonstrate that even the synthesis of 3,5-diketohexanoyl-CoA by a thiolase type condensation of three acetyl-CoA molecules was thermodynamically impossible under physiological conditions ${ }^{40}$.

\section{Fatty acid synthesis}

This difficulty was overcome when studies on fatty acid synthesis revealed malonyl-CoA as the building block for carbon-chain synthesis. In the condensation with malonyl-CoA the equilibrium is shifted to the side of the $\beta$-keto compound by the accompanying decarboxylation.

With these considerations in mind I postulated at the Gatlinburg conference in 1959 that malonyl-CoA is the precursor of all natural products with polyacetate structure ${ }^{41}$. In the following years this hypothesis has found experimental support by the investigations of many laboratories ${ }^{3}$. In these experiments, after feeding isotopically labelled precursors to living systems, the distribution of isotopic atoms in the synthesized products was determined by controlled chemical degradation and was found to be in agreement with the predictions. However, enzymatic studies in this field are rare and are mainly restricted to the exploration of fatty acid synthesis.

Before discussing the enzyme system of fatty acid synthesis I would like to dwell for a few moments on the enzyme responsible for the generation of malonyl-CoA by carboxylation of acetyl-CoA. This reaction belongs to the class of carboxylation processes, in which biotin participates as the coenzyme and acts as a $\mathrm{CO}_{2}$-carrier in the overall process (Figure 16). As elucidated by our studies ${ }^{12}$, biotin, covalently bonded to the protein, is first carboxylated 


\section{F. LYNEN}

by bicarbonate at the expense of ATP which is split into ADP and inorganic phosphate. The carboxybiotin enzyme thus formed then transfers its

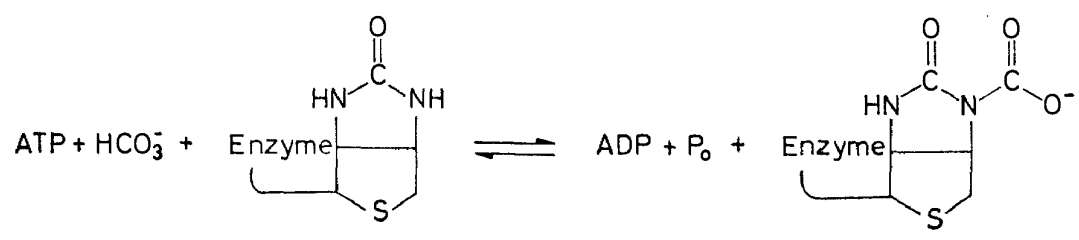

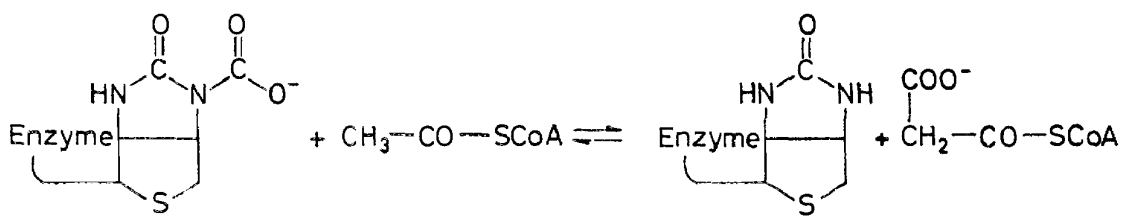

$$
\mathrm{ATP}+\mathrm{HCO}_{3}^{-}+\mathrm{Acetyl}-\mathrm{COA} \underset{(\text { Biotin-enzyme) }}{\rightleftharpoons} \mathrm{ADP}+\mathrm{P}_{0}+\text { Malonyl - } \mathrm{COA}
$$

Figure 16. Mechanism of the carboxylation of acetyl-CoA

carboxyl group to acetyl-CoA yielding malonyl-CoA. In the carboxylated enzyme $l^{\prime}-N$-carboxybiotin is bound to the enzyme protein through amide linkage at the $\epsilon$-amino group of a lysine residue (cf. Figure 16). The chemical reactivity of an "active carbonic acid" of this structure derives from the electron attraction of the ureido system. The bond between biotin and carbon dioxide is polarized towards nitrogen which augments the electrophilic character of the carboxyl group and its reaction with the enolate anion of acetyl-CoA. The process was found to be reversible and may occur by way of a concerted cyclic process as depicted in Figure 17.

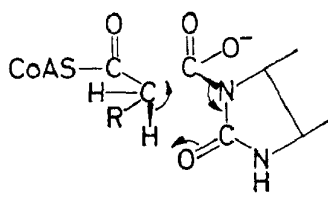

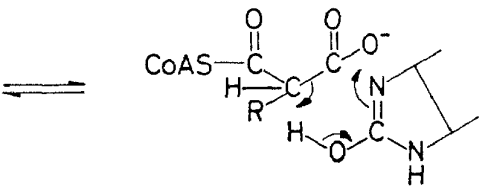

Figure 17. Chemical mechanism of transcarboxylation

Enzyme system of fatty acid synthesis

Insight into the chemical details of fatty acid synthesis, starting with malonyl-CoA, was first obtained in studies with the enzyme system of yeast ${ }^{\mathbf{4 0}, 42}$. From yeast cells, ruptured by vigorous shaking with glass beads, we were 
able to isolate a protein fraction 150 times more active than the crude extract. The purified enzyme, which we named fatty acid synthetase, proved to be homogeneous in the Tiselius apparatus and in the ultracentrifuge. Its molecular weight was estimated to be $2 \cdot 3$ million. It was found that 1 mole of fatty acid synthetase at $25^{\circ} \mathrm{C}$ and $\mathrm{pH} 6.8$ incorporates 3200 moles of malonyl-CoA into fatty acids per minute.

The synthesis of fatty acids from malonyl-CoA requires TPNH as a reducing agent and small amounts of acetyl-CoA in analogy with the avian and mammalian enzymes first studied by Wakil and Ganguly ${ }^{43}$ and by Brady ${ }^{44}$. The yeast enzyme synthesizes a mixture of palmityl- and stearylCoA, according to equation (3):

Acetyl-CoA $+n$ malonyl-CoA $+2 n$ TPNH $+2 n \mathrm{H}^{+} \longrightarrow$
$\mathrm{CH}_{3}\left(\mathrm{CH}_{2} \mathrm{CH}_{2}\right)_{n} \mathrm{CO}-\mathrm{CoA}+n \mathrm{CO}_{2}+n \mathrm{CoA}+2 n \mathrm{TPN}^{+}+\mathrm{H}_{2} \mathrm{O}$

(where $n=7$ or 8 )

Acetyl-CoA serves as "primer" of the process. Its $\mathrm{C}_{2}$-unit is recovered only in the methyl end of the fatty acid produced, indicating that $\mathrm{C}_{2}$-units from malonyl-CoA are added to the acetyl residue during the synthetic reaction. In its function as "primer", acetyl-CoA can be replaced by homologous saturated acyl-CoA compounds but not by their oxidation products, identified in studies on fatty acid oxidation. Furthermore, all attempts to find low molecular weight intermediates of the synthesis were unsuccessful.

The explanation for these puzzling observations was our discovery that the transformation of malonyl-CoA into fatty acids is achieved through intermediates which are covalently bound to sulphydryl groups of the synthetase $^{42}$. We found that two different types of sulphydryl groups have carrier function in the synthetic process. We denoted them as "central" and "peripheral" sulphydryl groups for purposes of differentiation. In the following scheme of fatty acid synthesis (Figure 18), first presented in 196142,45 they are distinguished by bold faced and normal print.

The synthetic process is initiated by the transfer of an acetyl residue from acetyl-CoA to the "peripheral" sulphydryl group, designated as "priming reaction". It is followed by the transfer of a malonyl residue from malonylCoA to the "central" sulphydryl group. The next step is a condensation between the enzyme-bound acetyl and malonyl groups resulting in the formation of acetoacetyl-enzyme with the concomitant liberation of carbon dioxide. The stepwise conversion of the $\beta$-keto acid into the saturated acid is accomplished by way of its reduction by TPNH to $\mathrm{D}(-)$ - $\beta$-hydroxybutyrylenzyme, followed by dehydration to crotonyl-enzyme and another TPNHlinked reduction to form the saturated butyryl-enzyme. In the second reduction step flavine mononucleotide (FMN) serves as hydrogen carrier. All the acyl residues involved in these chemical transformations are bound to the "central" sulphydryl group. At the stage of the saturated acid finally the butyryl group is transferred to the "peripheral" sulphydryl group, thus liberating the "central" sulphydryl group for introduction of the next malonyl residue. The reaction cycle can then proceed again, starting with 


\section{F. LYNEN}

Priming reaction:

$\mathrm{CH}_{3}-\mathrm{COSCOA}+{ }_{\mathrm{HS}}^{\mathrm{HS}}$-Enzyme $\rightleftharpoons \mathrm{CH}_{3}-\mathrm{COS}^{\mathrm{HS}}$-Enzyme+ $\mathrm{HSCOA}$

Chain lengthening reactions:

(1)

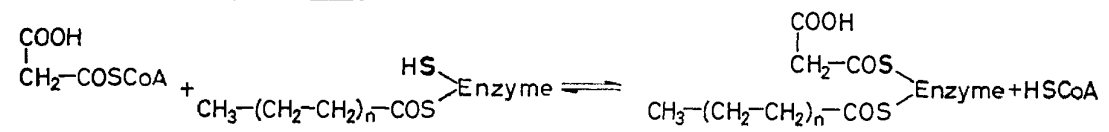

(2)

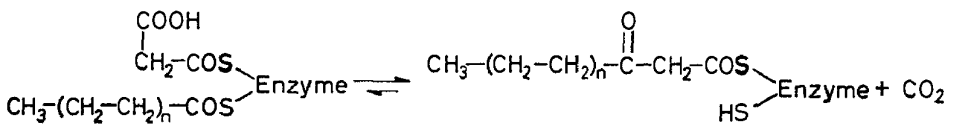

(3)

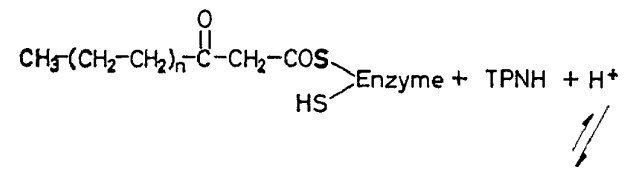

$\mathrm{HS}$ Enzyme $+\mathrm{CO}_{2}$

(4)

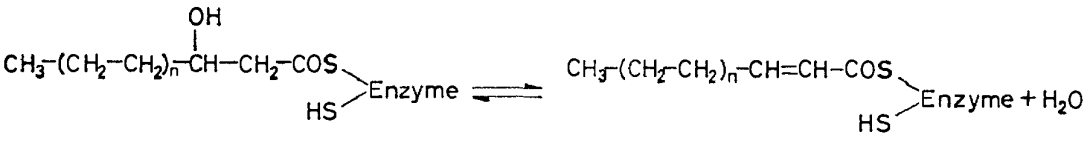

(5)

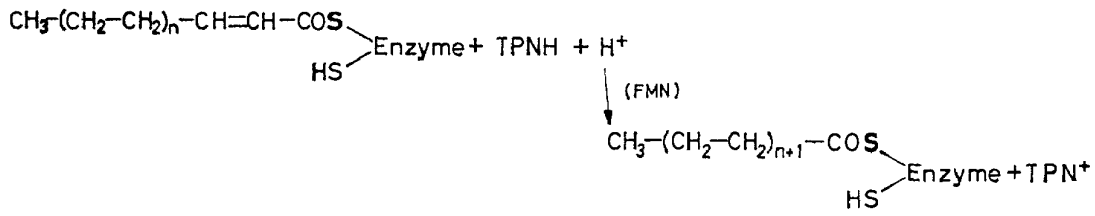

(6)

$\mathrm{CH}_{3}-\left(\mathrm{CH}_{2}-\mathrm{CH}_{2}\right)_{n+1}-\mathrm{COS}$

$$
\text { HS Enzyme }=
$$

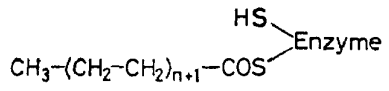

Terminal reaction:

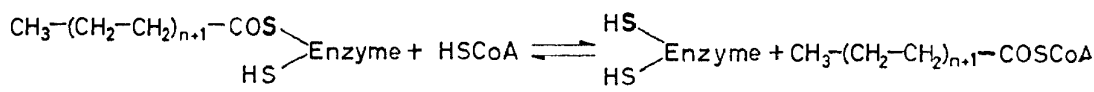

Figure 18. The mechanism of fatty acid synthesis

butyryl malonyl-enzyme, and is repeated until long chain saturated fatty acids with 16 or 18 carbon atoms are formed. In the terminal reaction step the acyl residue of palmitoyl- or stearoyl-enzyme is transferred from the "central" sulphydryl group to coenzyme A with the formation of palmitoylor stearoyl-CoA and the regenerated enzyme. The free enzyme can again react with acetyl- and malonyl-CoA thereby reinitiating the entire process.

This whole sequence of reactions is accomplished bv a multienzyme complex. Its functional unit was proposed to consist of a combination of seven different enzymes arranged around the "central" sulphydryl group in such a manner, that the intermediates bound covalently to this group can 


\section{BIOSYNTHETIC PATHWAYS FROM AGETATE TO NATURAL PRODUGTS}

come into close contact with the active sites of the participating enzymes (Figure 19).

We have now obtained experimental evidence that the "central" SHgroup belongs to an individual structural element ${ }^{46}$. As we originally assumed in our model, it is not part of one of the enzymic components. This means that the architecture of the fatty acid synthetase from yeast resembles the structure of the analogous enzyme system from bacteria. As the elegant experiments of Vagelos and his associates ${ }^{47}$ with the $E$. coli system have demonstrated, the "central" sulphydryl group, which carries the fatty acid intermediates, is bound to a readily dissociable protein of molecular weight about 9500, designated "acyl carrier protein". The bacterial enzyme system is not arranged in a stable multienzyme complex. Using standard methods of protein fractionation, it was possible to separate this enzyme system into enzymatically active individual components. A similar "acyl carrier protein" has been reported to be present in the corresponding enzyme system from plants ${ }^{48}$.

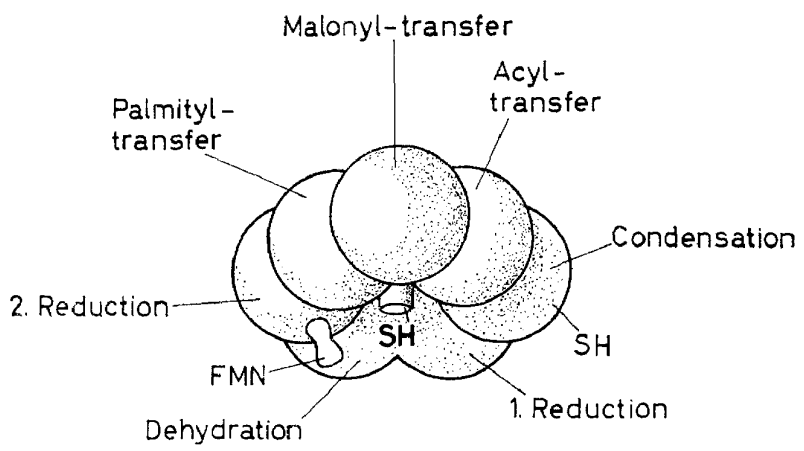

Figure 19. Hypothetical structure of the multienzyme complex of fatty acid synthetase. The seven enzyme units shown refer to the seven reactions (see Figure 18) occurring in fatty acid synthesis

Our repeated trials to split the multienzyme complex of yeast into its sub-units with retention of the individual enzyme activities were without success. In order to split the complex, it was necessary to use $0.2 \mathrm{M}$ sodium desoxycholate or $6 \mathrm{~m}$ urea which are such drastic conditions that most of the individual enzyme activities of fatty acid synthesis were lost ${ }^{49}$. In its stability the multienzyme complex of yeast fatty acid synthetase resembles the avian and mammalian synthetase complexes ${ }^{50,51}$.

From the standpoint of chemical mechanism all fatty acid synthetases studied so far seem to catalyze the same reaction sequence. One minor dissimilarity concerns the terminal reaction, which yields palmitoyl- and stearoyl-CoA with the yeast synthetase but free palmitate with the animal and bacterial enzyme systems. This difference may be due to the intervention of a hydrolytic enzyme which replaces the acyl transferase in the terminal reaction.

The structural organization of the fatty synthetase from yeast was verified by electron microscopy (Figure 20). By use of the negative staining technique 


\section{F. LYNEN}

with phosphotungstic acid Hofschneider was able to recognize single particles of oval shape surrounded by an equatorial ring. The longitudinal diameter of the particles is $250 \AA$, their cross diameter $210 \AA$. Unfortunately we cannot yet translate the information from electron micrographs into known schemes of structure. However, a structure composed of three circular sub-units fitting together seems possible. From the results of the chemical studies we have good evidence which supports the concept that each particle of molecular weight 2.3 million is composed of three functional assemblies.

$\frac{\text { Malonyl-transfer: }}{{ }^{14} \mathrm{C}-\text { Malonyl-CoA }}+$ Pantetheine $=$ CoA $+{ }^{14} \mathrm{C}$-Malonyl-pantetheine

Palmityl-transfer:

Palmityl-COA $+{ }^{14} \mathrm{C}-\mathrm{COA}=\mathrm{COA}+$ Palmityl $-{ }^{14} \mathrm{C}-\mathrm{COA}$

First reduction:

Acetoacetyl-S-AC + TPNH $+H^{+}=D(-)-\beta-$ Hydroxybutyryl-S-AC $+T_{P N}^{+}$

Second reduction:

Crotonyl $-\mathrm{S}-\mathrm{AC}+\mathrm{TPNH}+\mathrm{H}^{+} \stackrel{(\text { (FMN) }}{\longrightarrow}$ Butyryl-S-AC + TPN ${ }^{+}$

Dehydration:

$D(-)-\beta-H y d r o x y b u t y r y l-S-A C=$ Crotonyl-S-AC $+\mathrm{H}_{2} \mathrm{O}$

\section{Condensation:}

$$
\begin{gathered}
\text { Acetoacetyl-S-AC }+{ }^{14} \mathrm{CO}_{2}+\mathrm{HSCOA}= \\
\text { Where }-\mathrm{S}-\mathrm{AC}=-\mathrm{S}-\mathrm{CH}_{2}-\mathrm{CH}_{2}-\mathrm{NH}-\mathrm{CO}-\mathrm{CH}_{3}
\end{gathered}
$$

Figure 21. Summary of assay reactions with model substrates for the determination of the enzymatic components of fatty acid synthetase

In order to demonstrate the manifold catalytic activities attributed to the synthetase, we used model substrates in which the carboxylic acid intermediates of fatty acid synthesis were bound to pantetheine or $N$-acetylcysteamine (Figure 21). Lacking the strong covalent bond to the "central" sulphydryl group of the natural substrates, the affinity of these model substrates for the component enzymes is rather small. The defect can be circumvented, however, by employing high concentrations of the model substrates ${ }^{42}$. Studying the bacterial enzyme system, the natural substrates, that is, the carboxylic acid intermediates bound to the "acyl carrier protein" could be used ${ }^{52-55}$.

In addition to the experiments with model substrates we also used stoichiometric amounts of the yeast enzyme and demonstrated the enzyme bound intermediates directly ${ }^{45}$. As an example, short incubation of labelled $1-{ }^{14} \mathrm{C}$-acetyl-CoA with synthetase led to the formation of the radioactive acetyl-enzyme (Figure 22). It could be precipitated with trichloroacetic 
BIOSYNTHETIC PATHWAYS FROM ACETATE TO NATURAL PRODUCTS

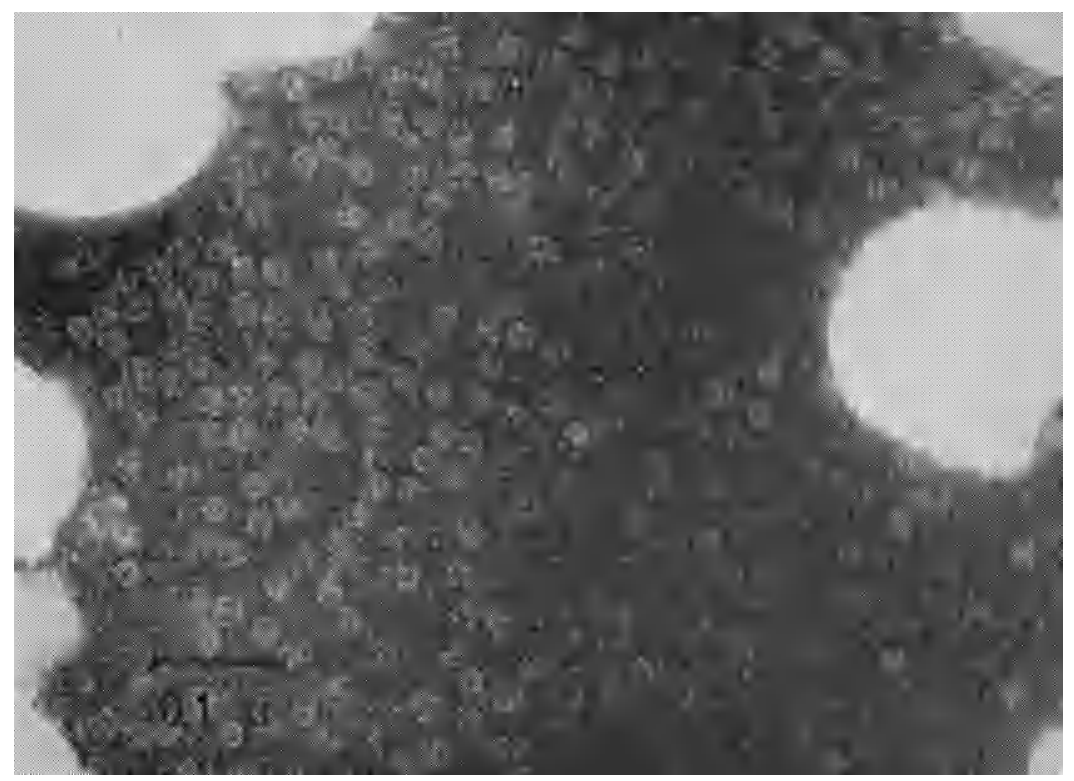

Figure 20. Electron micrograph of the purified fatty acid synthetase from yeast 
acid (TCA) with retention of radioactivity, indicating that the labelled acetyl group was covalently linked to the protein. When the radioactive acetylenzyme was separated from excess substrate by passing the reaction mixture

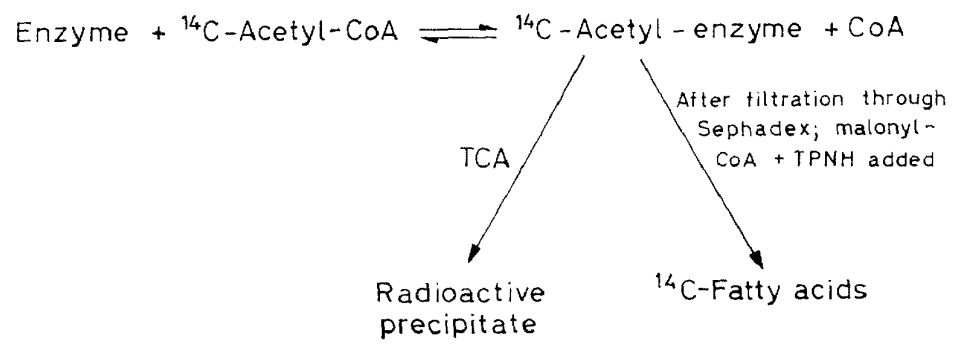

Figure 22. Scheme of the formation and transformation of acetyl-enzyme

over Sephadex and then incubated with malonyl-CoA and TPNH, more than 90 per cent of the protein bound acetic acid could be recovered in the fatty acids formed.

If the incubation mixture of labelled $1-{ }^{14} \mathrm{C}$-acetyl-CoA and synthetase was supplemented with malonyl-CoA a radioactive acetoacetyl-enzyme was formed. This could also be precipitated with trichloroacetic acid and yielded $3-{ }^{14} \mathrm{C}$-acetoacetate after mild alkaline hydrolysis. Our trials to isolate the native acetoacetyl-enzyme, employing the Sephadex technique failed, because acetoacetyl-enzyme is slowly decomposed spontaneously to free acetoacetate. In these experiments we measured the equilibrium constant of the formation of acetoacetyl-enzyme and found the following value ${ }^{12}$ :

$$
K_{\mathrm{eq}}=\frac{[\text { acetoacetyl-enzyme }] \times[\mathrm{CoA}]^{2} \times\left[\mathrm{CO}_{2}\right]}{[\text { acetyl-CoA }] \times[\text { malonyl-CoA }] \times[\text { enzyme }] \times\left[\mathrm{H}^{+}\right]}=2 \times 10^{5}\left(0^{\circ} \mathrm{C}\right)
$$

Eliminating the $\mathrm{H}^{+}$-concentration in this equation the equilibrium constant at $\mathrm{pH} 7 \cdot 0$ has the value:

$$
K_{\mathrm{eq}}^{\prime}=\frac{[\text { acetoacetyl-enzyme }] \times[\mathrm{CoA}]^{2} \times\left[\mathrm{CO}_{2}\right]}{[\text { acetyl-CoA }] \times[\text { malonyl-CoA }] \times[\text { enzyme }]}=2 \times 10^{-2}
$$

If we compare this equilibrium constant (condensation with malonyl-CoA) with the equilibrium constant of the thiolase reaction (condensation with acetyl-CoA, cf. page 144), which also generates an acetoacetyl thioester, the great thermodynamic advantage gained by the decarboxylation accompanying the condensation with malonyl-CoA becomes evident.

The favourable shift in the equilibrium position of the condensation reaction is ultimately due to the delivery of energy by ATP. At the expense of one pyrophosphate bond acetyl-CoA is first bound to $\mathrm{CO}_{2}$ as a carrier. After replacement of coenzyme A by the "central" sulphydryl group of the enzyme complex, condensation occurs with the acetyl residue bound to the "peripheral" sulphur. The condensation is accompanied by the release of carbon 


\section{F. LYNEN}

dioxide and the cleavage of one thioester bond. Because both reactants are in an "activated" state, the condensation reaction becomes very efficient.

From a chemical standpoint the condensation reaction may be classified as an acylation of malonic ester. The methylene group of the malonyl thioester, which is known to be more nucleophilic than the methyl group of an acetyl thioester, adds to the electrophilic carbonyl carbon of the sulphur bound carboxylic acid, as shown in the upper half of Figure 23. The intermediate formed is converted into the $\beta$-keto acyl derivative by the subsequent elimination of mercaptan and carbon dioxide. An alternative reaction mechanism might be the concerted process shown on the lower half of Figure 23. A decision between the two mechanisms may be reached by tracer experiments with heavy water.
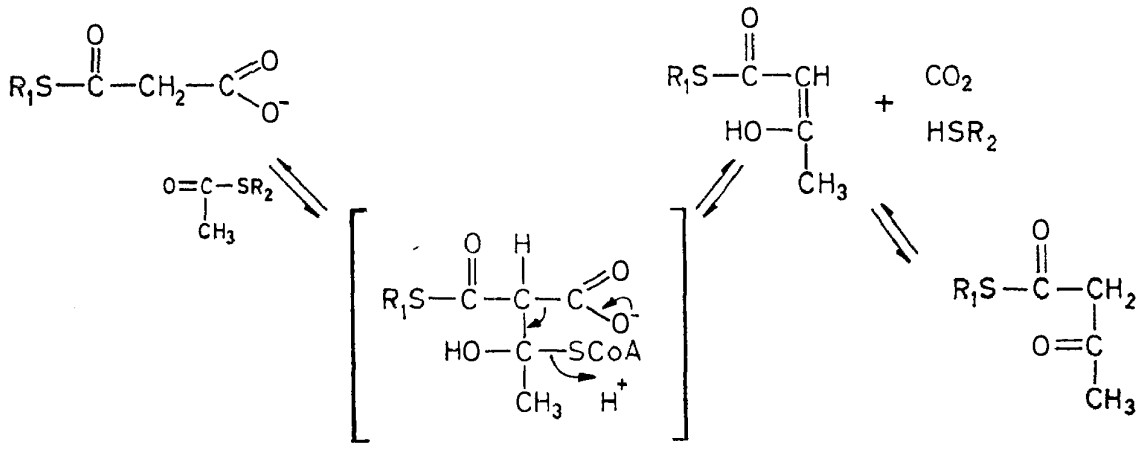

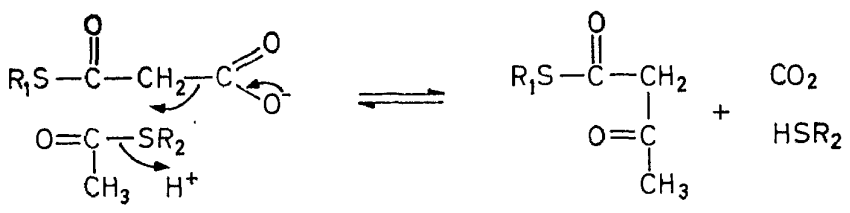

Figure 23. Mechanism of the formation of $\beta$-keto acids from malonyl thioester

Investigation of the chemical nature of the two types of sulphydryl groups involved in fatty acid synthesis first led to the identification of the "peripheral" one as belonging to cysteine. In addition, we have obtained experimental evidence, that this sulphydryl group is located in the condensing enzyme components of the multienzyme complex ${ }^{56}$.

The carrier of the "central" sulphydryl group of the yeast fatty acid synthetase was recently identified as 4'-phosphopantetheine bound through phosphodiester linkage with the hydroxyl group of a serine residue of the polypeptide ${ }^{57}$. This kind of attachment was discovered by Vagelos ${ }^{58}$ and by Wakil ${ }^{59}$ in studies on the chemical structure of the acyl carrier protein of $E$. coli, and was also found in the mammalian fatty acid synthetase complex ${ }^{51}$. 


\section{BIOSYNTHETIC PATHWAYS FROM ACETATE TO NATURAL PRODUCTS}

Our evidence for the occurrence of $4^{\prime}$-phosphopantetheine stems from experiments in which the purified fatty acid synthetase of yeast was heated at $\mathrm{pH} 12$ at $98^{\circ}$ for one hour, following the procedure described by Vagelos ${ }^{58}$. Under these conditions the protein released a low molecular weight compound, which after benzoylation and further purification was identified as S-benzoyl-4'-phosphopantetheine by chemical analysis and by comparison with the authentic compound (Figure 24). The release of $4^{\prime}$-phosphopantetheine by mild alkaline treatment is in accord with the concept of an elimination reaction in the $\beta$-position of a polypeptide bound serine.

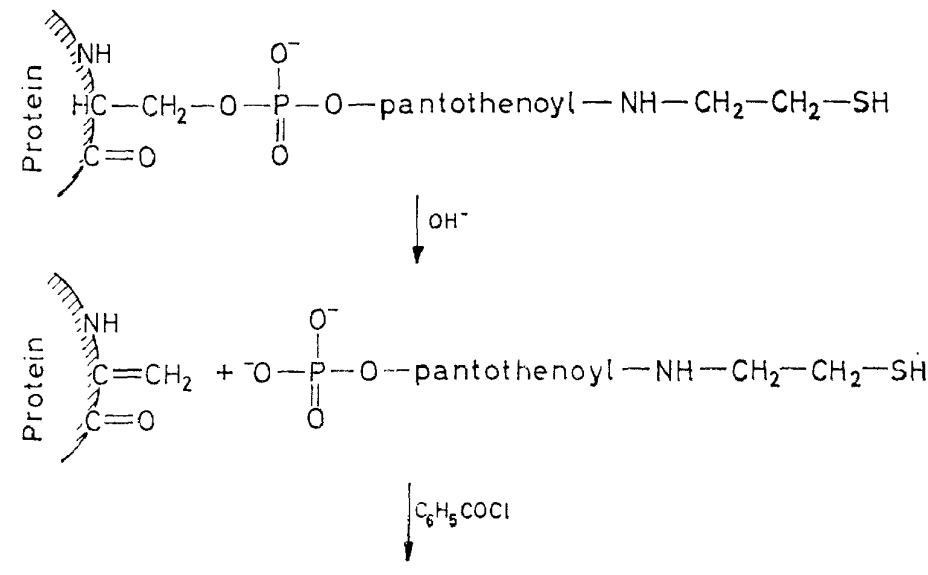

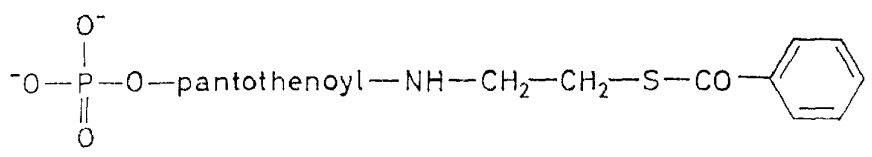

Figure 24. Schematic representation of the identification of protein bound 4'-phosphopantetheine

The presence of $4^{\prime}$-phosphopantetheine is further supported by experiments with yeast cells grown in a medium containing ${ }^{14} \mathrm{C}$-labelled pantothenic acid. Wells, as a guest in my laboratory, isolated the fatty acid synthetase from these cells and found the purified enzyme to contain three moles of radioactive pantothenate covalently bound per mole of enzyme ${ }^{5}$.

The attachment through 4'-phosphopantetheine provides a flexible arm for the "central" sulphydryl group, conceivably permitting rotation of the latter between the various enzymes. In this manner it is easily possible to bring the fatty acid intermediates, bound covalently to this sulphydryl group, in close contact with the active site of each component enzyme which has only limited freedom of motion in the stable multienzyme complex. This is schematically illustrated in Figure 25, where the circles should indicate the active sites of the participating enzymes.

In the course of our investigations which led to the identification of the 


\section{F. LYNEN}

"peripheral" and "central" sulphydryl groups we found to our great surprise that acetate and malonate are not bound to the enzyme complex exclusively via sulphur atoms ${ }^{60}$. In these experiments we used the lability of thiol esters towards performic acid as a tool for the characterization.

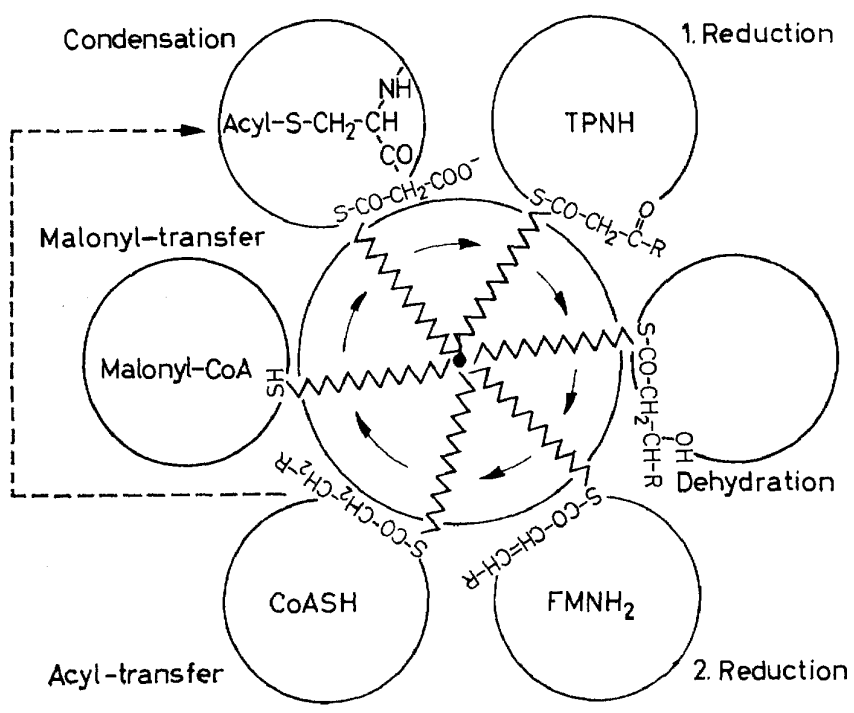

Figure 25. Reaction scheme illustrating individual events during fatty acid synthesis on the multienzyme complex

Performic acid oxidizes thiolesters to the corresponding sulphonic acids with release of the carboxylic acids (equation 4),

$$
\mathrm{R}-\mathrm{S}-\stackrel{\mathrm{O}}{\mathrm{C}}-\mathrm{R}^{\prime} \stackrel{\mathrm{H}-\stackrel{\mathrm{O}}{\mathrm{C}}-\mathrm{OOH}}{\longrightarrow} \mathrm{R}-\mathrm{SO}_{3} \mathrm{H}+\mathrm{R}^{\prime}-\mathrm{COOH} \quad \ldots
$$

In Table 2 the results of an experiment with radioactive ${ }^{14} \mathrm{C}$-acetyl enzyme are shown. The labelled enzyme was prepared by the interaction of constant amounts of enzyme with varying concentrations of ${ }^{1-14} \mathrm{C}$-acetyl-CoA, followed by precipitation with trichloroacetic acid and measuring the protein bound radioactivity. From this table it can be seen that the transfer of radioactive acetate to the enzyme depends on the concentration of acetylCoA used, as expected, if the acetyl transfer is a reversible process. However, in the whole concentration range studied, only about 50 per cent of the radioactive acetyl groups bound to the protein were released by treatment with performic acid.

From this and other experiments we came to the conclusion that the acyl transfer to the multienzyme complex is initiated with the transfer to some non-sulphydryl acceptor group $\mathrm{X}$ in the protein. As illustrated in Figure 26 malonyl and acetyl residues are transferred from group $\mathrm{X}$ to the "central" 
Table 2. Formation of ${ }^{14} \mathrm{C}$-acetyl enzyme and release of ${ }^{14} \mathrm{C}$-acetic acid by oxidation with performic acid

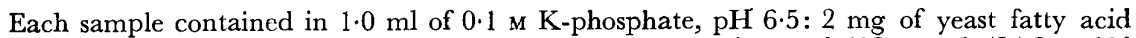
synthetase (sp. activity 850 milliunits), $10 \mu$ moles of cysteine and ${ }^{14} \mathrm{C}$-acetyl $\left(24.8 \times 10^{B}\right.$ c.p.m. $/ \mu$ mole) in the concentrations listed in the table. The mixture was incubated for 5 min at $0^{\circ} \mathrm{C}$ and the reaction stopped by the addition of $0.3 \mathrm{ml}$ of $3 \mathrm{~m}$ trichloroacetic acid. After careful washing the precipitated protein was dissolved in $0.5 \mathrm{ml}$ of 98 per cent formic acid, $0.2 \mathrm{ml}$ aliquots dried on strips of Whatman 1 paper and the radioactivity measured before and after $12 \mathrm{~h}$ exposure to an atmosphere of performic acid. Before measurement in the scintillation counter the paper strips were dried in vacuum over potassium hydroxide. The radioactivity values listed in the table are based on $2 \mathrm{mg}$ protein.

\begin{tabular}{|c|c|c|c|}
\hline \multirow{2}{*}{$\begin{array}{l}{ }^{14} C-A c e t y l-C o A \\
\left(\times 10^{-6} \mathrm{M}\right)\end{array}$} & \multicolumn{2}{|c|}{$\begin{array}{l}\text { Protein bound radioactivity } \\
\text { (c.p.m.) }\end{array}$} & \multirow{2}{*}{$\begin{array}{c}\text { Stable radioactivity } \\
(\%)\end{array}$} \\
\hline & Direct & After oxidation & \\
\hline $\begin{array}{r}2 \\
4 \\
6 \\
10 \\
15 \\
20 \\
30 \\
40 \\
50\end{array}$ & $\begin{array}{l}15623 \\
19582 \\
23847 \\
29325 \\
38590 \\
39830 \\
40817 \\
45437 \\
50113\end{array}$ & $\begin{array}{r}7825 \\
9100 \\
10045 \\
13260 \\
17270 \\
17731 \\
18921 \\
20741 \\
22921\end{array}$ & $\begin{array}{l}50 \\
46 \cdot 5 \\
42 \\
45 \\
45 \\
45 \\
46 \\
45 \cdot 5 \\
45 \cdot 5\end{array}$ \\
\hline
\end{tabular}

sulphydryl group. The further transfer to the "peripheral" sulphydryl group is specific for acetate and its higher homologues.

According to our scheme, the acyl residue of malonyl enzyme is bound to both group X and the "central" sulphydryl group. In agreement with this

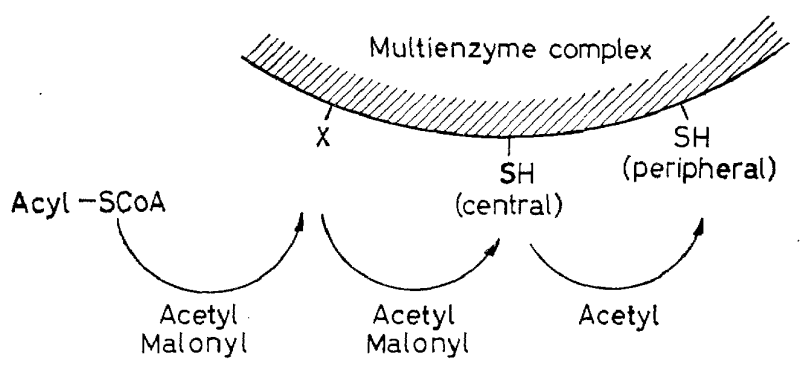

Figure 26. Specificity of acyl transfer to the different acceptor groups on the multienzyme complex

assumption, more than one radioactive acyl peptides were isolated from the peptic hydrolysate of ${ }^{3-14} \mathrm{C}$-malonyl enzyme by chromatography on DEAE-Sephadex. This is illustrated in Figure 27. The fastest moving fraction, signified A, was split by performic acid, whereas fractions B and C were stable to the same treatment. From the acid hydrolysate of malonyl peptide A, cysteamine and $\beta$-alanine were identified by ion exchange chromatography ${ }^{60}$. Since cysteine was absent, this peptide is derived from the polypeptide area around the "central" sulphydryl group. 


\section{F. LYNEN}

The radioactivity of the fractions $B$ and $G$ was due to the presence of a ${ }^{14} \mathrm{C}$-malonyl heptapeptide and a ${ }^{14} \mathrm{C}$-malonyl pentapeptide which could be purified by chromatographic procedures. The acyl pentapeptide contained serine besides histidine, glycine, alanine, and leucine (G-terminal position).

DEAE - Sephadex chromatography of the peptic hydrolysate

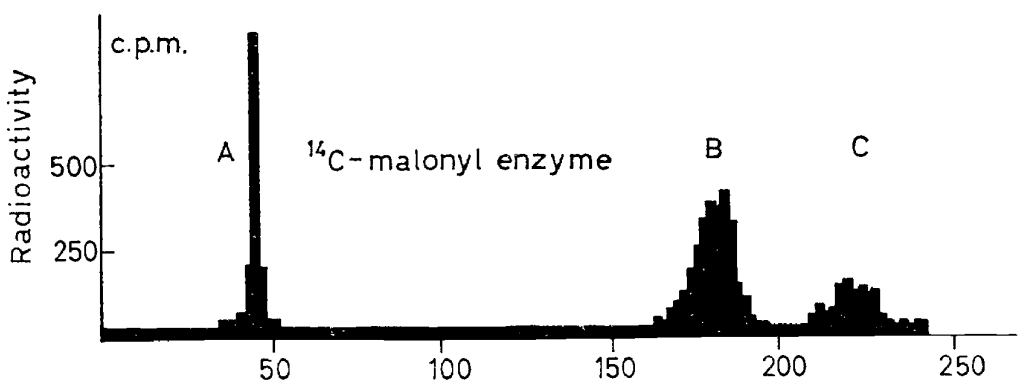

Figure 27. Chromatography of the peptic hydrolysate of ${ }^{14} \mathrm{C}$-malonyl-enzyme on DEAESephadex. For the preparation of ${ }^{14} \mathrm{C}$-malonyl enzyme $1.6 \mathrm{~g}$ of synthetase (sp. activity 550 milliunits $/ \mathrm{mg})$ and $28 \mu$ moles of $3-{ }^{14} \mathrm{C}$-malonyl-CoA $\left(1.2 \times 10^{6}\right.$ c.p.m. $\left./ \mu \mathrm{mole}\right)$ in $120 \mathrm{ml}$ of 0.05 м K-phosphate buffer, $\mathrm{pH} 6.5$, were incubated for $2 \mathrm{~min}$ at $22^{\circ} \mathrm{C}$. The reaction was stopped by the addition of $6 \mathrm{ml}$ of $3 \mathrm{M}$ trichloroacetic acid. After careful washing, the precipitated protein was suspended in 21 of $0.01 \mathrm{~N} \mathrm{HCl}$ and digested by incubation with $160 \mathrm{mg}$ of crystalline pepsin at room temperature. After evaporation of the water in vacuum the residue was dissolved in $7 \mathrm{ml}$ of pyridine acetate buffer, $\mathrm{pH} 6.5$. Insoluble material was removed by centrifugation, and the clear solution chromatographed on a column of DEAESephadex $(2 \cdot 1 \times 150 \mathrm{~cm}$ ). The eluting solvent until fraction 70 (volume of fraction: $6 \mathrm{ml}$ ) was $0.05 \mathrm{~m}$ pyridine acetate buffer, $\mathrm{pH} 6.25$; thereafter a gradient was employed. For this purpose $0.2 \mathrm{M}$ acetic acid was continuously introduced into a mixing chamber containing $200 \mathrm{ml}$ of $0.05 \mathrm{M}$ pyridine acetate buffer, $\mathrm{pH} 6.25$

The acyl heptapeptide was similar but contained, in addition, glycine and glutamic acid. These results seem to indicate that group $\mathrm{X}$ is identical with the hydroxyl group of serine. Further experiments should indicate whether the carrier group $\mathrm{X}$ is connected with the enzyme components that catalyze acyl transfer reactions.

Another unsolved problem is why fatty acid synthetase produces mainly palmitic and stearic acid but no carboxylic acids of shorter chain length. Earlier we assumed that this might be due to the specificity of the enzymic component which terminates the process by transferring the fatty acid radical from the enzyme to coenzyme $\mathrm{A}^{12}$. However, when we studied the relationship between rate of acyl transfer and chain length of the acid, it was found to our great surprise that the saturated acids from $\mathrm{C}_{6}$ to $\mathrm{C}_{20}$ were transferred at nearly equal rates ${ }^{61}$. Consequently other factors must be responsible for stopping the synthesis at the stage of the $\mathrm{C}_{16}$ and $\mathrm{C}_{18}$ acids.

\section{Physiological regula tion of fatty acid synthesis}

In conclusion I would like to discuss briefly our present views about the rate control of fatty acid synthesis. This will bring us back to the biotin 
enzyme acetyl-CoA carboxylase, the step recognized to be rate-limiting in fatty acid synthesis in warmblooded organisms ${ }^{62}$. As has been shown in several laboratories, one of the unique features of acetyl-CoA carboxylase from animal sources is its activation by tri- and dicarboxylic acids, especially citrate. Extensive studies of this stimulatory effect have revealed that the increased activity is connected with an aggregation of the enzyme (cf. ref. 62). Another interesting property of the acetyl-CoA carboxylase is its inhibition by long-chain acyl-CoA derivatives, as was discovered by Bortz. It was found that the inhibition increased with growing chain-length of the fatty acid radical. Numa carried out systematic kinetic studies on the inhibition by palmitoyl-CoA with the purified enzyme. He found that the inhibition was competitive with regard to citrate, the enzyme activator $^{62,63}$.

Our studies have been restricted to the properties of the enzyme, in vitro, and must be cautiously interpreted with regard to the physiological regulation of fatty acid synthesis. Nevertheless, it is conceivable that our findings might represent part of the cellular control mechanism. Raised levels of fatty acids in the blood are associated with starvation and diabetes, conditions in which fatty acid synthesis is known to be almost fully blocked. Further, it could be shown in normal animals that a diet rich in fat or the infusion of chylomicrons led to a drastic inhibition of fatty acid synthesis. Related to these observations it was found that the level of the higher acylCoA compounds in liver is markedly increased under all conditions of depressed fatty acid synthesis (Table 3). Therefore it is tempting to speculate

Table 3. Long chain acyl-CoA content of rat liver

\begin{tabular}{|c|c|c|}
\hline Status of rats & $\begin{array}{l}\text { Acyl-CoA per } g \text { fresh liver } \\
\text { (m } \mu \text { moles) }\end{array}$ & Researchers \\
\hline $\begin{array}{l}\text { Normal } \\
\text { Starved for } 24 \mathrm{~h}\end{array}$ & $\begin{array}{l}14.9 \pm 0.5 \\
57.7 \pm 7.9\end{array}$ & $\left\{\begin{array}{l}\text { Bortz and } \\
\text { Lynen (1963) }\end{array}\right.$ \\
\hline $\begin{array}{l}\text { Normal } \\
\text { Starved for } 48 \mathrm{~h} \\
\text { After fat feeding } \\
\text { Diabetic }\end{array}$ & $\begin{array}{l}52 \cdot 8 \pm 8 \cdot 6 \\
110 \cdot 0 \pm 28 \\
135 \cdot 0 \pm 23 \\
92 \cdot 0 \pm 20\end{array}$ & $\left\{\begin{array}{l}\text { Tubbs and } \\
\text { Garland } \\
(1963,1964)\end{array}\right.$ \\
\hline $\begin{array}{l}\text { Normal } \\
\text { Diabetic } \\
\text { Diabetic and insulin-injected }\end{array}$ & $\begin{array}{l}14 \cdot 5 \pm 2 \cdot 6 \\
58 \cdot 2 \pm 10 \cdot 6 \\
16 \cdot 0 \pm 2 \cdot 3\end{array}$ & $\left\{\begin{array}{l}\text { Wieland; } \\
\text { Felts et al. } \\
(1964)\end{array}\right.$ \\
\hline
\end{tabular}

that fatty acid synthesis is under typical feedback control. As can be seen from the pattern of lipogenesis (Figure 28), the inhibitory long-chain acylCoA derivatives represent the last molecules in the synthetic sequence before subsequent incorporation into the "complex lipids". Furthermore, the inhibition would affect the enzyme acetyl-CoA carboxylase, the point at 


\section{F. LYNEN}

which fatty acid synthesis branches off from the many other reaction paths of acetyl-CoA.

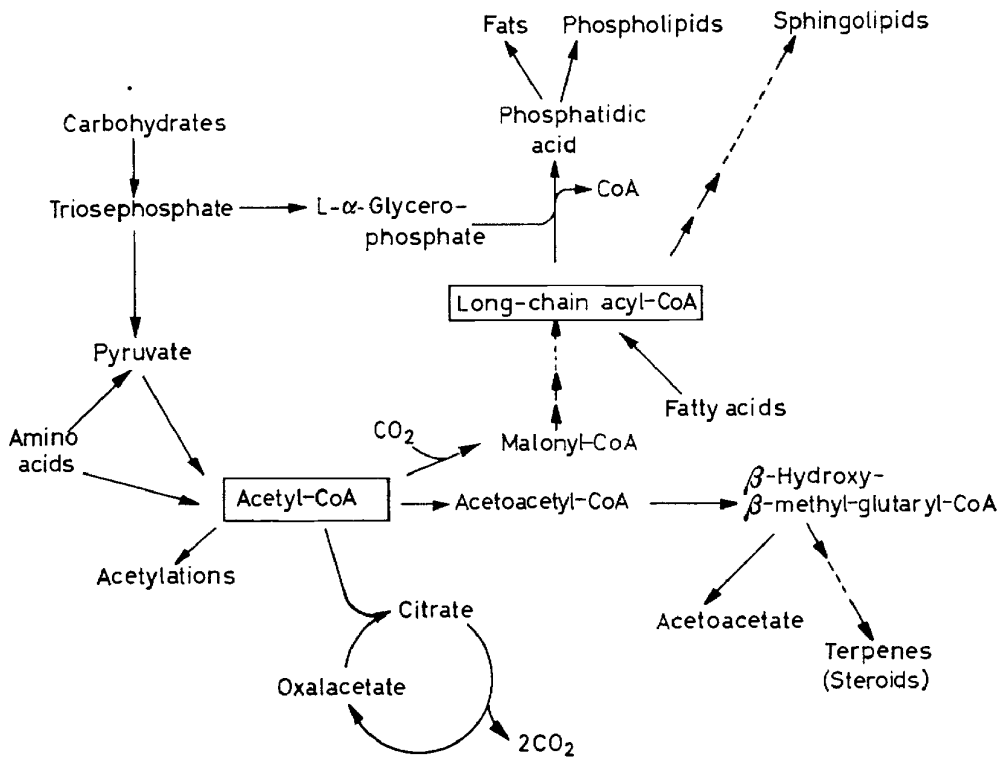

Figure 28. The biological pathway of lipogenesis

\section{Biosynthesis of more complex polyacetate structures}

Let us finally examine the implications of the studies on fatty acid synthesis for the biosynthesis of the more complex polyacetate structures. It has often been remarked that no intermediates in the postulated biogenesis have been found $^{3}$. Therefore one might imagine that these substances are also synthesized on multienzyme complexes with covalently bound intermediates ${ }^{40,42}$. With this view one could reconcile to the concept of Ehrensvärd ${ }^{64}$ and of Woodward ${ }^{39}$ which they developed for the biosynthesis of polycyclic quinones and macrolides. Such enzyme complexes represent, so to speak, the matrices on which the raw materials are assembled piece by piece. The product would be released from the enzyme complex only in the final form, thus explaining the inability to detect intermediates. This supposition is illustrated in Figure 29 for the case of 6-methylsalicylic acid synthesis. Looking at the depicted reaction sequence, we see acyl transfer reactions, condensations, reductions, and dehydrations as in the case of fatty acid synthesis. What is responsible for the fact that the same kind of enzyme activities can give rise to fatty acids on the one hand and 6-methylsalicylic acid on the other? Is this solely the consequence of the specificities of the component enzymes, or does the specific architecture of the multienzyme complex, by determining the order of reactions, play a decisive role? This is 
<smiles>Cc1cccc(O)c1C(=O)O</smiles><smiles>O=C(O)CCCCCOC(=O)CC(=O)O</smiles><smiles>C[13CH][13C](C)=O</smiles>

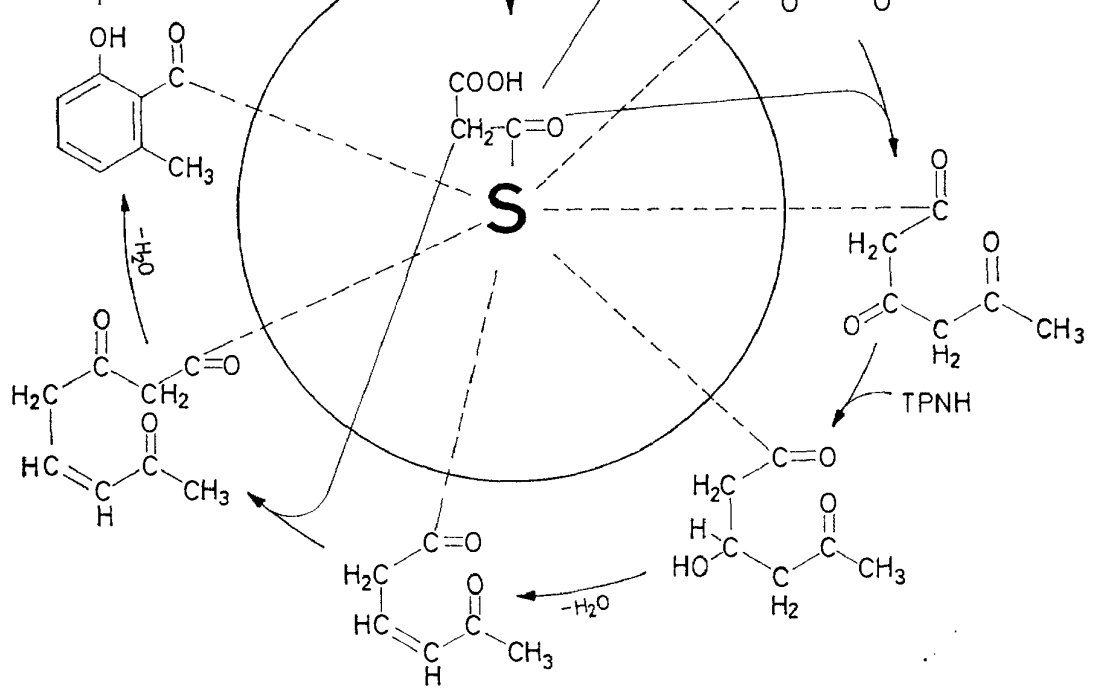

Figure 29. Hypothetical reaction scheme of 6-methylsalicylic acid synthesis on a multienzyme complex

an important question which research on the enzyme level will have to answer.

Finally, it is a pleasant duty to mention the enthusiasm and devotion of all my associates who have made our work possible, and whose names are given in the various references. I also thank Professor $W . W$. Wells for his kind help in the preparation of this manuscript.

\section{References}

${ }^{1}$ L. Ruzicka. Experientia 9, 357 (1953).

2 A. J. Birch. In Fortschritte der Chemie organischer Naturstoffe (Ed. L. Zechmeister), Vol. 14, p. 186, Springer-Verlag, Wien, 1957.

${ }^{3} \mathrm{~J}$. H. Richards, and J. B. Hendrickson. The Biosynthesis of Steroids, Terpenes, andAcetogenins, W. A. Benjamin, Inc., New York-Amsterdam, 1964.

4 S. Chaykin, J. Law, A. H. Phillips, T. T. Tchen, and K. Bloch. Proc. Natl. Acad. Sci. U.S. 44, 998 (1958).

B F. Lynen, H. Eggerer, U. Henning, and I. Kessel. Angew. Chem. 70, 738 (1958).

B B. L. Archer, D. Barnard, E. G. Cockbain, J. W. Cornforth, R. H. Cornforth, and G. Popják. Proc. Roy. Soc. Ser. B. 163, 519 (1965/66). 


\section{F. LYNEN}

${ }^{7}$ H. Eggerer. Chem. Ber. 94, 174 (1961).

${ }^{8}$ W. S. Johnson, and R. A. Bell. Tetrahedron Letters 12, 27 (1960).

${ }^{9}$ F. Lynen, B. W. Agranoff, H. Eggerer, U. Henning, and E. M. Möslein. Angew Chem. 71, 657 (1959).

10 U. Henning, E. M. Möslein, B. Arreguin, and F. Lynen. Biochem. Z. 333, 534 (1961).

11 B. L. Archer, B. G. Audley, E. G. Cockbain, and G. P. MacSweeney. Biochem. J. 89, 565 (1963).

12 F. Lynen. Angew. Chem. 77, 929 (1965).

${ }_{13}$ A. Eschenmoser, L. Ruzicka, O. Jeger, and D. Arigoni. Helv. Chim. Acta 38, 1890 (1955).

14 P. Karrer, and A. Helfenstein. Helv. Chim. Acta 14, 78 (1931).

15 J. W. Cornforth, R. H. Cornforth, G. Donninger, and G. Popják. Proc. Roy. Soc. Ser. B. 163, $492(1965 / 66)$.

${ }^{16}$ A. F. Wagner, and K. Folkers. Adv. Enzym. 23, 471 (1961).

17 I. F. Durr, and H. Rudney. J. Biol. Chem. 235, 2572 (1960).

18 J. Knappe, E. Ringelmann, and F. Lynen. Biochem. Z. 332, 195 (1959).

$19 \mathrm{~J}$. Rétey, and F. Lynen. Unpublished experiments.

20 M. Lindberg, C. Yuan, A. de Waard, and K. Bloch. Biochemistry 1, 182 (1962).

${ }^{21}$ L. Jaenicke, and F. Lynen. In The Enzymes (Eds. P. D. Boyer, H. Lardy, and K. Myrbäck)

Vol. III, p. 3, Academic Press, New York (1960).

22 F. Lynen. Fed. Proc. 12, 683 (1953).

${ }^{23}$ U. Gehring. Thesis, University of Munich (1964).

${ }^{24}$ U. Gehring, and F. Lynen. Unpublished results.

${ }^{25}$ H. Beinert, and P. G. Stansly. J. Biol. Chem. 204, 67 (1953).

${ }^{26}$ J. D. Brodie, G. Wasson, and J. W. Porter. J. Biol. Chem. 238, 1294 (1963).

27 D. Bloomfield, and K. Bloch. J. Biol. Chem. 235, 337 (1960).

${ }^{28}$ N. L. R. Bucher, K. McGarrahan, E. Gould, and A. V. Loud. J. Biol. Chem. 234, 262 (1959).

${ }^{29}$ G. M. Tomkins, H. Sheppard, and I. L. Chaikoff. J. Biol. Chem. 201, 137 (1953).

${ }^{30}$ R. G. Langdon, and K. Bloch. J. Biol. Chem. 202, 77 (1953).

31 I. D. Frantz, Jr., H. S. Schneider, and B. T. Hinkelman. J. Biol. Chem. 206, 465 (1954).

32 G. M. Tomkins, and I. L. Chaikoff. J. Biol. Chem. 196, 569 (1952).

${ }^{33}$ T. T. Hutchens, J. T. Van Bruggen, R. M. Cockburn, and E. S. West. J. Biol. Chem. 208, 115 (1954).

34 R. G. Gould, V. L. Bell, and E. M. Lilly. Radiation Res. 5, 609 (1956).

${ }^{35}$ I. D. Frantz, Jr., and B. T. Hinkelman. J. Exptl. Med. 101, 225 (1955).

${ }^{36}$ N. L. R. Bucher, P. Overath, and F. Lynen. Biochem. Biophys. Acta 40, 491 (1960).

37 D. Regen, C. Riepertinger, B. Hamprecht, and F. Lynen. Biochem. Z. 346, 78 (1966).

${ }^{38}$ J. N. Collie. J. Chem. Soc. 122, 329 (1893); 787, 1806 (1907).

39 R. B. Woodward. Angew. Chem. 69, 50 (1957).

${ }^{40}$ F. Lynen, and M. Tada. Angew. Chem. 73, 513 (1961).

41 F. Lynen. J. Cell. Comp. Physiol. 54, suppl. 1, 33 (1959).

42 F. Lynen. Fed. Proc. 20, 941 (1961).

${ }^{43}$ S. J. Wakil, and J. Ganguly. J. Am. Chem. Soc. 81, 2597 (1959).

${ }^{44}$ R. O. Brady. Proc. Natl. Acad. Sci. U.S. 44, 993 (1958).

${ }_{45}$ F. Lynen. In Proceedings of the Robert A. Welch Foundation Conferences on Chemical Research, V. Molecular structure and biochemical reactions; p. 293, Houston, Texas (1962).

${ }^{48} \mathrm{~K}$. Willecke. Unpublished experiments.

47 P. W. Majerus, A. W. Alberts, and P. R. Vagelos. Proc. Natl. Acad. Sci. U.S. 53, 410 (1965).

48 P. Overath, and P. K. Stumpf. J. Biol. Chem. 239, 4103 (1964).

49 A. Hagen. Thesis, University of Munich (1963).

${ }^{50}$ R. Bressler, and S. J. Wakil. J. Biol. Chem. 236, 1643 (1961).

51 A. R. Larrabee, E. G. McDaniel, H. A. Bakerman, and P. R. Vagelos. Proc. Natl. Acad. Sci. U.S. 54, 267 (1965).

52 P. W. Majerus, A. W. Alberts, and P. R. Vagelos. Proc. Natl. Acad. Sci. U.S. 51, 1231 (1964).

53 A. W. Alberts, P. W. Majerus, B. Talamo, and P. R. Vagelos. Biochemistry 3, 1563 (1964).

${ }^{54}$ S. J. Wakil, E. L. Pugh, and F. Sauer. Proc. Natl. Acad. Sci. U.S. 52, 106 (1964).

${ }^{55}$ F. Sauer, E. L. Pugh, S. J. Wakil, R. Delaney, and R. L. Hill. Proc. Natl. Acad. Sci. U.S 52, 1360 (1964). 
${ }^{56}$ F. Lynen. In New Perspectives in Biology (Ed: M. Sela), (B.B.A. Library Volume 4), p. 132, Elsevier Publishing Company, Amsterdam (1964).

${ }^{\circ 7}$ W. W. Wells, J. Schultz, and F. Lynen. Proc. Natl. Acad. Sci. U.S. 56, 633 (1966).

s\& P. W. Majerus, A. W. Alberts, and P. R. Vagelos. J. Biol. Chem. 240, 4723 (1965).

50 E. L. Pugh, and S. J. Wakil. J. Biol. Chem. 240, 4727 (1965).

Bo F. Lynen. In Aspects of Yeast Metabolism, Guiness Symposium, Dublin. To be published in" 1967.

61 E. Schweizer. Thesis, University of Munich (1963).

${ }^{2}$ S. Numa, W. M. Bortz, and F. Lynen. In Advances in Enzyme Regulation (Ed: G. Weber), Vol. III, p. 407, Pergamon Press, London (1965).

63 S. Numa, E. Ringelmann, and F. Lynen. Biochem. Z. 343, 243 (1965).

64 G. Ehrensvärd, and S. Gatenbeck. In: Hauptvorträge des XVII. Internationalen Kongress für Reine und Angewandte Chemie, Vol. II, p. 73, Verlag Chemic,Weinheim/ Bergstraße (1960). 